\title{
KSIĘGA ABDIASZA W SEPTUAGINCIE
}

Księga Abdiasza, choć krótka (liczy zaledwie 21 wersetów; najkrótsza w Biblii Hebrajskiej), jest bardzo trudna. Trudności przejawiają się w warstwie językowej i tekstualnej, ale przede wszystkim w tym, co dotyczy jej treści, teologii i interpretacji. Święty Hieronim (a za nim wielu egzegetów) napisał: „Quanto brevius est, tanto difficilius” („Tak jak jest krótka, tak i trudna”). Jako księga złorzecząca (niektórzy zauważają w niej wręcz „kipiący gniew” i ,język nacechowany przesadą"2), jest niemal w całości (poza ostatnimi wersetami zapowiadającymi zbawienie dla Izraela) mową przeciw Edomitom (najbliższym sąsiadom biblijnych Izraelitów, którzy, według Księgi Rodzaju, pochodzili od Ezawa, brata bliźniaka Jakuba ${ }^{3}$ ), na skutek czego zawsze stanowiła niemałe wyzwanie zwłaszcza dla jej chrześcijańskich interpretatorów. ${ }^{4}$ Różne trudne pytania rodzące się na poziomie oryginalnego tekstu hebrajskiego zyskały nową wartość

1 E. Zenger, Il libro dei Dodici profeti, w: tenże (red.), Introduzione all'AnticoTestamento, Editrice Queriniana, Brescia 2013, s. 887. Zob. także: M. Harl, C. Dogniez, L. Brottier i in. (red.), La Bible d'Alexandrie. [XXIII], Les Douze Prophètes. 4-9, Joël, Abdiou, Jonas, Naoum, Ambakoum, Sophonie (traduction du texte grec de la Septante, introduction et notes), Éditions du Cerf, Paris 1999, s. 83 (dalej: B d'A XXIII.4-9).

2 V. Salanga, Księga Abdiasza, w: W.R. Farmer (red. nauk.), S. McEvenue, A.J. Levoratti, D.L. Dungan (współred.), W. Chrostowski (red. nauk. wyd. pol.), T. Mieszkowski, P. Pachciarek (współred.), Międzynarodowy komentarz do Pisma Świętego. Komentarz katolicki i ekumeniczny na XXI wiek, Verbinum, Wydawnictwo Księży Werbistów, Warszawa 2001, s. 1021.

3 Por. Rdz 25,19-24 (zwł. w. 23).

4 Zapewne także z tego powodu Księga Abdiasza jest nieobecna w liturgii Kościoła rzymskokatolickiego; por. V. Salanga, Księga Abdiasza, s. 1023. 
odniesione do starożytnych wersji tej księgi. Niełatwy i niejednoznaczny język hebrajski Księgi Abdiasza był wyzwaniem dla jej starożytnych tłumaczy, którzy prezentowali rozbieżne interpretacje. Najstarsza jest zawarta w Septuagincie (LXXAbd).

Ten grecki przekład jest szczególnie ważny, ponieważ przedstawia sposób rozumienia sięgający czasów przedchrześcijańskich, hellenistycznych, które mocno podkreślały temat zagrożeń dla Izraela ze strony innych narodów (por. powstałe w podobnym czasie Księgi Machabejskie czy grecka Księga Judyty). To powodowało, że temat Księgi Abdiasza był ważny i mógł stać się przedmiotem aktualizacji do sytuacji wspólnoty, która była jego odbiorcą. Mimo że przekład LXXAbd, podobnie jak pozostałe Księgi Proroków Mniejszych, których jest częścią, ${ }^{5}$ pozostaje stosunkowo wierny BH (,,reasonably close to the MT"6), zawiera jednocześnie pewne interesujące zmiany, które pozwalają lepiej zrozumieć sposób pracy tłumacza.

Dodatkowo ważne jest także w kontekście rozważań nad LXXAbd, że - podobnie, jak oryginał hebrajski - LXXAbd można porównać z paralelnymi tekstami przeciw Edomowi, szczególnie zawartym w Księdze Jeremiasza: Jr 29,8-237 (według numeracji hebrajskiej 49,7-22), a zwłaszcza z wersetami początkowymi: Jr 29,8-17 (według numeracji hebrajskiej 49,7-16). Takiego porównania między tymi

5 Na temat jedności tekstu Dwunastu Proroków w LXX zob. paragraf dot. tekstu LXXAbd.

6 G.E. Howard, The Twelve Prophets. To the Reader, w: A. Pietersma, B. G. Wright (red.), A New English Translation of the Septuagint. And the Other Greek Translations Traditionally Included under that Title, New York-Oxford 2007, s. 777 (dalej: NETS).

7 Taka numeracja za dwoma opracowaniami LXX: J. Ziegler (red.), Septuaginta. Vetus Testamentum Graecum. Auctoritate Academiae Scientiarum Gottingensis editum, t. XV: Jeremias - Baruch - Threni - Epistula Jeremiae, Vandenhoeck \& Ruprecht, Göttingen 1957 oraz H. B. Swete (red.), The Old Testament in Greek According to the Septuagint, t. III, The University Press, Cambridge 192233 zaś według wydania LXX: A. Rahlfs, R. Hanhart (red.), Septuaginta. Id est Vetus Testamentum graece iuxta LXX interpretes, Deutsche Bibelgessellschaft, Stuttgart 2006 chodzi o LXXJr 30,8-23. W niniejszym artykule stosowana jest numeracja wydania z Göttingen. 
tekstami na gruncie wersji hebrajskiej dokonywano wielokrotnie (ukazując wpływ obu tekstów na siebie), ${ }^{8}$ jednak ich porównanie w przekładach zawartych w LXX może wiele wnieść do rozumienia kierunku, w którym szły aktualizacje orędzia obu ksiąg, umożliwia pełniejszą analizę pracy tłumacza LXXAbd, a także może pomóc w datacji greckiego przekładu Księgi Abdiasza.

\section{Kontekst historyczny hebrajskiej i greckiej Księgi Abdiasza}

Na początku warto przyjrzeć się domniemanej datacji hebrajskiej i greckiej Księgi Abdiasza, tym bardziej że jej orędzie jest mocno związane z konkretną sytuacją historyczną, która z pewnością wpłynęła na pierwotną treść, a potem także na interpretację zawartą w przekładzie.

Większość badaczy zgodna jest co do faktu, że hebrajska Księga Abdiasza treściowo odzwierciedla sytuację z VI w. przed Chr., a więc okoliczności wygnania babilońskiego. ${ }^{9}$ Księga powstała albo w tym czasie, albo bezpośrednio po nim (najpopularniejsze teorie mówią o VI lub V w. przed Chr. - na czas niedługo przez powstaniem Księgi Joela, która we fragmencie 3,5 zdaje się cytować Abd w. 17). ${ }^{10}$

8 Omówienie tego tematu (wraz z literaturą przedmiotową) zob. dalej.

9 Dawniej datowano ją nawet na IX w. przed Chr.; por. B d'A XXIII.4-9, s. 84. Omówienie tematu datacji hebrajskiej Ksiegi Abdiasza (wraz z bibliografią) zob. także: R. Mason, Micah, Nahum, Obadiah, OT Guides, JSOT Press, Sheffield 1991, s. 85-108; E. Ben Zvi, A Historical-Critical Study of the Book of Obadiah, Beiheft zur Zeitschrift für die Alttestamentliche Wissenschaft 242, Walter de Griuyter, New York 1996. Por. także: M. A. Sweney, The Twelve Prophets. Volume one: Hosea, Joel, Amos, Obadiah, Jonah, Berit Olam. Studies in Hebrew Narrative \& Poetry, The Liturgical Press, Collegville MI 2000, s. 280-281; V. Salanga, Księga Abdiasza, s. 1021-1022; E. D. Mallon, Księga Abdiasza, w: R. E. Brown (red.), J. A. Fitzmyer, R. E. Murphy (współred.), W. Chrostowski (red. nauk. wyd. pol.), Katolicki Komentarz Biblijny, Prymasowska Seria Biblijna 17, Oficyna Wydawnicza „Vocatio”, Warszawa 2001, s. 834-835; J. Renkema, Data Relevant to the Dating of the Prophecy of Obadiah, w: H. F. Van Rooy (red.), Past, Present, Future: The Deuteronomistic History and the Prophets, Brill, Leiden 2000, s. 251-262.

10 Zob. B d'A XXIII.4-9, s. 84. 
Czas VI w. przed Chr. to okres dominacji imperium babilońskiego, które wywierało wpływ na małe narody zamieszkujące Syro-Palestynę. Oba narody wspominane w Księdze Abdiasza, Izraelici i Edomici, a także wszystkie inne zamieszkujące Syro-Palestynę, doświadczyły ucisku ze strony imperium babilońskiego, przeciw któremu próbowano zawiązywać rozmaite koalicje. ${ }^{11} \mathrm{~W}$ ostatnich dniach istnienia monarchii Judy Edomici, a także inne sąsiednie małe narody (Moabici, Ammonici, mieszkańcy Tyru i Sydonu), przyłączyły się do spisku, o czym wspomina Jr 27 (zwł. w. 3). ${ }^{12}$ W konsekwencji Babilon wysyłał ekspedycje karne, których skutki okazały się katastrofalne: monarchia Judy została unicestwiona, jej elity deportowane w trzech kolejnych etapach do Babilonii, ${ }^{13}$ a najbardziej

11 Na temat Edomu i Izraela, oraz złożonej sytuacji historycznej VI w. przed Chr. zob.: M. Weippert, Edom. Studien zur Geschichte der Edomiter auf Grund schriftlicher un archäologischer Quellen, Tübingen 1971; J. M. Myers, Edom and Judah in the Sixth-Fifth Centuries B.C., Near Eastern Studies (Fest. Albright), Baltimore 1971, s. 377-392; U. Kellermann, Israel und Edom. Studien zum Edomhass Israels in 6.-4. Jahrhundert v.Chr. (książka habilitacyjna), Münster 1975; B. Hartberger, „An den Wassern von Babylon...". Psalm 137 auf dem Hintergrund von Jeremia 51, der biblischen Edom-Traditionen und babylonischer Originalquellen, Bonner biblische Beiträge 63, Frankfurt a. M.-Bonn 1986; B. Dicou, Edom, Israel's Brother and Antagonist: The Role of Edom in Biblical Prophecy and Story, Journal for the Study of the Old Testament Supplement Series (JSOTS) 169, JSOT Press, Sheffield 1994; E. Ben Zvi, A Historical-Critical Study of the Book of Obadiah; E. B. Farisani, The ethnic tensions between the Edomites and the Israelites in Obadiah, Journal for Semitics-Tydskrif vir Semitistiek, 19(2010) nr 2, s. 566-583. Zob. także bardziej teologiczne opracownia: J. J. Krause, Tradition, history, and our story: some observations on Jacob and Esau in the books of Obadiah and Malachi, Journal for the Study of the Old Testament 32/2008, s. 475-486; oraz A. C. Hagedorn, Die Anderen im Spiegel: Israels Auseinandersetzung mit den Völkern in den Büchern Nahum, Zefanja, Obadja und Joel, Beihefte zur Zeitschrift für die alttestamentliche Wissenschaft 414, De Gruyter, Berlin-Boston (Mass.) 2011.

12 E. D. Mallon, Ksiega Abdiasza, s. 834-835. Por. J. M. Myers, Edom and Judah in the Sixth-Fifth Centuries B.C., Near Eastern Studies (Fest. Albright), Baltimore 1971, s. 377-392.

13 Na ten temat zob. szerokie opracowanie wraz z bibliografią: W. Chrostowski, Babilońskie deportacje mieszkańców Jerozolimy i Judy (597-582 r. przed Chr.), w: tenże, Babilońskie deportacje mieszkańców Jerozolimy 
symbolicznym i bolesnym wydarzeniem tego czasu było zburzenie świątyni jerozolimskiej w 586 r. przed Chr. Podobny los podzieliły wszystkie niewielkie sąsiadujące ze sobą narody, można więc przypuszczać, że wśród nich również Edomici. O najazdach babilońskich na sąsiednie względem Izraela narody wspomina nawet Józef Flawiusz w Dawnych dziejach Izraela (10.9.7, par. 181-182), wyliczając wśród narodów podbitych przez Babilon Ammonitów i Moabitów, ale $-\mathrm{z}$ jakiegoś powodu - przemilczając Edomitów. Jego narracja pokrywa się z tą, którą odnajdujemy wcześniej w różnych miejscach Biblii Hebrajskiej, także na kartach Ksiegi Abdiasza. ${ }^{14}$ Edomitów postrzega się jako tych, którzy zdradzili Izraelitów (może jako konsekwencja niezachowania koalicji? ${ }^{15}$ ), a w tekście księgi znajduje się wzmianka o tym, jakoby Edom splądrował Jerozolimę, a nawet na rozstajach dróg mordował ocalałych zbiegów, ${ }^{16}$ czego nie poświadczają żadne źródła historyczne (ze starożytnych dokumentów w ogóle nie wynika, by Edom miał w tych walkach jakikolwiek udział ${ }^{17}$ ).

i Judy oraz inne studia, Rozprawy i Studia Biblijne 34, Oficyna Wydawnicza „Vocatio”, Warszawa 2009, s. 35-79.

14 I innych ksiąg; por. J. Dykehouse, Biblical evidence from Obadiah and Psalm 137 for an Edomite treaty betrayal of Judah in the sixth century B.C.E., Antiguo Oriente 11/2013, s. 75-128.

15 M. A. Sweeney, The Twelve Prophets. Volume one: Hosea, Joel, Amos, Obadiah, Jonah, Berit Olam. Studies in Hebrew Narrative \& Poetry, The Liturgical Press, Collegville (MI) 2000, s. 281.

16 V. Salanga, Księga Abdiasza, s. 1021; por. J. Dykehouse, Biblical evidence from Obadiah and Psalm 137 for an Edomite treaty betrayal of Judah in the sixth century B.C.E., s. 75-128.

17 Argumenty za taką postawą Edomitów znajdujemy jedynie w Biblii Hebrajskiej i innych starożytnych źródłach żydowskich. Według niektórych badaczy księgi biblijne wzajemnie utwierdzają taki obraz Edomu i niejako udowadniają taką ich postawę (por. opracowanie J. Dykehouse, Biblical evidence from Obadiah and Psalm 137 for an Edomite treaty betrayal of Judah in the sixth century B.C.E., s. 75-128). Rzadziej jednak w opracowaniach konfrontuje się tę jednostronną narrację izraelską ze źródłami historycznymi. Dzieje się tak dlatego, że niektórym trudno przyjąć tak mocną ideologizację ksiąg biblijnych, niektóre komentarze do Abd eufemistycznie piszą - nie chcąc podważać przekazu Księgi - że „,z dokumentów nie wynika w sposób jednoznaczny, jaką rolę w wydarzeniach tych odegrał Edom”, 
Edomici są opisywani w Księdze Abdiasza jako zdrajcy, bliscy sąsiedzi (najbliżsi przez legendarne pochodzenie), którzy pozostawili zbratany naród Izraela bez pomocy, stając się sprzymierzeńcem najeźdźcy, czyli imperium babilońskiego. Prorok Abdiasz oskarża ich o stanie z boku i przyglądanie się cierpieniu bratniego narodu, a nawet o wykorzystanie słabości, której doświadczył już po upadku Jerozolimy, gdy Edomici mieli wykorzystać słabość pozostałych przy życiu mieszkańców Judy, przenosząc się nieopodal Hebronu kilkadziesiąt kilometrów od Jerozolimy, po splądrowaniu przez Babilończyków ich własnej stolicy - Bosry. ${ }^{18}$ Księga Abdiasza jest swoistym lamentem nad upadłą Jerozolimą, ${ }^{19}$ ale nade wszystko nad obojętnością sąsiadów, którzy przez tę obojętność stają się zdrajcami i wrogami (na których spadnie zasłużona kara), choć przecież sami padli ofiarą babilońskich najazdów.

Inne tradycje biblijne (także dawniejsze chronologicznie) przedstawiają Edomitów jako skłóconych z Izraelitami: ${ }^{20}$ już w czasie wyjścia Izraelitów z Egiptu (gdy Edom odmówił narodowi wybranemu przejścia przez swoje terytorium w stronę Ziemi Obiecanej; por. Lb 20,14-21); w okresie monarchii Juda i Edom pozostawały w stałym konflikcie - Edom raz był wolny, raz znajdował się pod panowaniem Judy (z Edomitami walczyli i podporządkowywali sobie ich Saul, Dawid i Salomon: 2Sm 8,13[LXX] i 1Krn 18,12-13; 1Krl 11,15-16 oraz 11,25b[LXX]; spór dotyczył m.in. portu Esjon Geber - dzisiejsze Ejlat; Edomitów wspomina się w historii Jozafata - 2Krl 8,20-22; Jorama - 2Krl 22,49; Amazjasza - 2Krl 14,7; oraz Azariasza - 2Krl

por. Księga Abdiasza, w: J. H. Walton, V. H. Matthews, M. W. Chavalas (red.), W. Chrostowski (red. nauk. wyd. pol.), Komentarz historyczno-kulturowy do Biblii Hebrajskiej, Prymasowska Seria Biblijna 24, Oficyna Wydawnicza „Vocatio”, Warszawa 2005, s. 890. Por. A.C. Hagedorn, Die Anderen im Spiegel: Israels Auseinandersetzung mit den Völkern in den Büchern Nahum, Zefanja, Obadja und Joel.

18 V. Salanga, Księga Abdiasza, s. 1021.

19 Dlatego podnoszona idea, że księga była czytana jako lamentacja nad upadkiem Świętego Miasta w liturgii świątynnej.

20 Na ten temat zob.m.in. opracowanie: B. Dicou, Edom, Israel's Brother and Antagonist: The Role of Edom in Biblical Prophecy and Story. 
14,22). ${ }^{21}$ Edomici stali się w narracjach biblijnych wręcz symbolem wroga. Mowy przeciw nim pojawiają się w tradycjach profetycznych Starego Testamentu, pośród nich najstarszą jest ta zawarta w Księdze Amosa (Am 1,11-12), ale są one obecne i w innych księgach prorockich (Iz 34,5-17; 63,1-6; Ez 25,12-14; 35,2-15; Ml 1,2-5; i w związku z Jeremiaszem Lam 4,21-22). ${ }^{22}$ Także w późniejszych tradycjach biblijnych, nawet w Psalmach (zwł. Ps 137,7), w których dostrzec można pewną prawidłowość: im bardziej oddalano się od czasów faktycznych zdarzeń z VI w. przed Chr., tym bardziej obraz Edomu ulegał pogorszeniu, a nawet alegoryzacji, stając się paradygmatem wszelkiego wroga Izraelitów. ${ }^{23}$

Niestety, nie zachowały się analogiczne do biblijnych pisma Edomitów dotyczące Izraela, zwłaszcza w kontekście wydarzeń z VI w. przed Chr. i relacji z Izraelitami - a porównanie narracji historycznej dotyczącej wspólnych wydarzeń zaprezentowane przez oba narody mogłoby być interesujące, a w celu większego obiektywizmu przekazu historycznego - wręcz konieczne i bardzo owocne, tak jak dla obrazu stosunków izraelsko-moabickich wartościowa stała się konfrontacja tekstu biblijnego z tekstem steli Meszy, króla Moabu (jedyny tego typu zachowany dokument) ${ }^{24}$. Interpretacja izraelska - jedyna, którą znamy - jest więc dominująca, co nie znaczy, że niejednostronna, poddana ideologizacji czy kreacji historii, którą powtarzały kolejne pokolenia, także Józef Flawiusz.

\footnotetext{
21 Por. E. D. Mallon, Księga Abdiasza, s. 834.

22 Por. M. A. Sweeney, The Twelve Prophets. Volume one: Hosea, Joel, Amos, Obadiah, Jonah, s. 281.

23 Por. rozdział: Origins of Edom's Role as a Type, w: B. Dicou, Edom, Israel's Brother and Antagonist: The Role of Edom in Biblical Prophecy and Story, s. 158-204.

$24 \mathrm{Na}$ temat zob. choćby w języku polskim: S. Gądecki, Stela Meszy, króla Moabu, w: tenże, Archeologia biblijna, t. 1, Gniezno 1994, s. 312-313. Albo inne opracowania wprowadzające: A. Lemaire, La stèle de Mésha et l'histoire de l'ancien Israël, w: D. Garrone, F. Israel (red.), Storia e tradizioni di Israele, Paideia Editrice, Brescia 1991, s. 143-169; tenże, The Mesha Stele and the Omri dynasty, w: L. L. Grabbe (red.), Ahab Agonistes, T \& T Clark, London 2007, s. 135-144 A. Niccacci, The Stele of Mesha and the Bible: Verbal System and Narrativity, Orientalia 63/1994, s. 226-248.
} 
Taki sposób myślenia o sąsiadach istniał zresztą w wielu księgach prorockich, począwszy od Księgi Amosa, która krytykę narodu biblijnego Izraela zaczęła od krytyki wielu jego sąsiadów (Am 1-2), a skończywszy na całkowicie złorzeczącej Księdze Nahuma (której autor cieszy się z upadku Niniwy). Ów partykularyzm izraelski, którego wyrazem jest negatywna postawa wobec sąsiadów (obecna zresztą powszechnie także u innych ludów starożytnego Bliskiego Wschodu), będzie z kolei skrytykowany (czy wręcz wyśmiany) choćby przez Księgę Jonasza. ${ }^{25}$ Może z tego powodu w kanonie (zarówno hebrajskim, jak i greckim) Księga Abdiasza umieszczona jest tuż przed Księgą Jonasza (która jest oryginalnym głosem w debacie dotyczącej partykularyzmu izraelskiego). ${ }^{26}$

${ }_{25}$ Analizę tego problemu debaty wewnątrz zbioru Dwunastu Proroków, zob. B. Strzałkowska, Ksiegga Nahuma i Księga Jonasza: debata wewnątrz zbioru Dwunastu Proroków? Collectanea Theologica 81(2011) nr 4, s. 29-46.

${ }^{26}$ W BH Księga Abdiasza to czwarta księga pośród Dwunastu Proroków, zaś w LXX - piąta. Por. także: M. E. Biddle, Obadiah-Jonah-Micah in canonical context: the nature of prophetic literature and hermeneutics, Interpretation, 61/2007, s. 154-166; F. Bargellini, Il ruolo canonico di Gioele, Abdia e Giona. Elementi per una lettura unitaria dei XII profeti Minori, Rivista biblica, 55/2007, s. 145-163; oraz nowe studium: A. Sirikivuya Mumbere, ,'Le règne à YHWH”: pour lire Abdias-Jonas et Michée, cas d'une cohérence polyphonique des XII dans le texte massorétique, w: J.-H. Fabry (red.), The books of the Twelve Prophets: Minor Prophets - major theologies, Peeters, Leuven-Paris-Bristol 2018, s. 365-386.

Szerzej na temat położenia Abd w kanonie greckim zob.: P.-M. Bogaert, L'Organisation des grands recueils prophétiques, w: J. Vermeylen (red.), Le Livre d'Isaïe, Bibliotheca Ephemeridum Theologicarum Lovanieniuum 81, Leuven 1989, s. 147-153 (zwł. s. 148-149); B. Jones, The Formation of the Book of the Twelve: A Study in Text and Canon, Scholars Press, Atlanta 1995; B d'A XXIII.4-9, Paris 1999, s. 86; K. Jeppesen, "The Lord God Has Spoken and Who Will Not Prophesy?" From Osee to Jonas in the Septuagint, w: C. McCarthy, J. F. Healey (red.), Biblical and Near Eastern Essays. Festschrift for K.J. Cathcart, Sheffield Academic Press, Sheffield 2004, s. 105-117; M. Aussedat, Le regroupement des livres prophétiques dans la Septante d'après le témoignage des chaînes exégétiques, w: M. K. H. Peters (red.), XII Congress of the International Organization for Septuagint and Cognate Studies Leiden 2004, Society of Biblical Literature. Septuagint and Cognate Studies 54, Atlanta 2006, s. 169-185; M. Beck, Das Dodekapropheton als Anthologie, Zeitschrift für die Alttestamentliche Wissenschaft 118/2006, s. 558-583; J.M. Dines, Verbal 
Takie podejście do sąsiadów charakteryzowało również grecki przekład Księgi Abdiasza, powstały w środowisku Żydów aleksandryjskich, najprawdopodobniej w II w. przed Chr., ${ }^{27}$ a nawet w jakimś sensie je zradykalizowało (zob. dalej). To zrozumiałe, że naród żyjący na obczyźnie, w kontekście obcej kultury hellenistycznego Egiptu, mógł dostrzegać zagrożenie płynące z tej współegzystencji i mógł mieć potrzebę wyróżnienia tematów, które podkreślały wartość własnej kultury i wybrania, przy - czasem - umniejszaniu innych. W takim kontekście można też widzieć powstanie greckiego przekładu Księgi Abdiasza.

Przekład ten powstał wraz z pozostałymi tzw. Prorokami Mniejszymi, i nie ma obecnie wątpliwości, że wszystkie księgi zbioru Dwunastu Proroków, mające podobny charakter, należy traktować zwłaszcza w ich wersji w LXX - razem. ${ }^{28}$ Przemawiają za tym argumenty wewnętrzne i zewnętrzne.

and Thematic Links between the Books of the Twelve in Greek and Their Relevance to the Differing Manuscript Sequences, w: R. Albertz, J. D. Nogalski, J. Wöhrle (red.), Perspectives on the Formation of the Book of the Twelve: Methodological Foundations - Redactional Process - Historical Insigths, De Gruyter, Berlin 2012, s. 355-370; J. D. Nogalski, Not just another nation. Obadiah's placement in the Book of the Twelve, w: tamże, s. 89-107; J. M. Dines, The Minor Prophets, w: J. K. Aitken (red.), The T\&T Clark Companion to the Septuagint, Bloomsbury T\&T Clark, London i in. 2015, s. 439-440.

27 Na temat miejsca i datacji LXXAbd zob. choćby: J.M. Dines, The Minor Prophets, s. 441; por. także B. Strzałkowska, Księga Aggeusza w Septuagincie, Collectanea Theologica 82(2012) nr 4, s. 77-81.

28 Na temat przekładu Dwunastu Proroków w LXX w ich jedności zob.: B. Strzałkowska, Księga Ozeasza w Septuuagincie, Collectanea Theologica 86(2016) nr 4, s. 78-86; J. M. Dines, The Minor Prophets, s. 439-440; A. Schart, Dodekapropheton. Das Zwölfprophetenbuch, w: M. Karrer, W. Kraus i in. (red.), Septuaginta Deutsch. Erläuterungen und Kommentare zum gieschischen Alten Testament, t. II: Psalme bis Daniel, Stuttgart 2009, s. 2275-2286; G. E. Howard, The Twelve Prophets. To the Reader, w: NETS, s. 777-781 (zwł. s. 780-781). Zob. dawniejsze opracowania: A. Kaminka, Studien zur Septuaginta an der Hand der zwölf kleinen Prophetenbücher, Monatsschrift für Geschichte und Wissenschaft des Judentums 72, Breslau 1928, s. 49-60, 242-273; L. Treitel, Wert und Bedeutung der Septuaginta zu den 12 kleinen Propheten, Monatsschrift für Geschichte und Wissenschaft 
Te pierwsze ukazują, że przekładu dokonała najprawdopodobniej ta sama osoba (grupa osób), na co wskazuje styl i charakter przekładu - jednakowy we wszystkich księgach zbioru. ${ }^{29}$ Wskazuje na to także tradycja biblijna, zwłaszcza Księga Syracha, która w w. 49,10 (w LXX) wspomina Dwunastu Proroków razem (chodzi

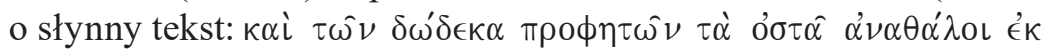

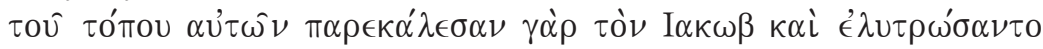

des Judentums 73/1929, s. 232-234; J. Ziegler, Die Einheit der Septuaginta zum Zwölfprophetenbuch, Beilage zum Vorlegungsverzeichnis der Staatl. Akademie zu Braunsberg/Ostpr. 5/1934, s. 1-16; tenże, Studien zur Verwetung der Septuaginta im Zwölfprophetenbuch, Zeitschrift für die alttestamentliche Wissenschaft 60/1944, s. 107-131; P. Kahle, Die Lederrolle mit dem griechischen Text der Kleinen Propheten und das Problem der LXX, Theologische Literaturzeitung 79/1954, s. 81-94; J. Ziegler, Zur Dodekapropheton- $L X X$, Ephemerides Theologicae Lovanienses 38/1962, s. 904-906; C. R. Harrison, The Unity of the Minor Prophets in the LXX: A Reexamination of the Question, Bulletin of the International Organization for Septuagint and Cognate Studies 21/1988, s. 55-72 ; T. Mouraoka, In Defence of the Unity of the Septuagint Minor Prophets, Annual of the Japanese Biblical Institute 15/1989, s. 25-36; C. Dogniez, Le Dieu des armées dans le Dodekapropheton, w: B. A. Taylor (red.), IX Congress of the International Organization for Septuagint and Cognate Studies, Cambridge 1995, Society of Biblical Literature Septuagint and Cognate Studies Series 45, Atlanta 1997, s. 19-36; taż, Fautes de traduction, ou bonnes traductions? w: B. A. Taylor (red.), X Congress of the International Organization for Septuagint and Cognate Studies, Oslo 1998, Society of Biblical Literature Septuagint and Cognate Studies Series 51, Atlanta 2001, s. 241-261; J. Joosten, A Septuagintal Translation Technique in the Minor Prophets. The Elimination of Verbal Repetitions, w: G. Martínez Florentino (red.), Interpreting Translation, Bibliotheca Ephemeridum Theologicarum Lovaniensium 192, Leuven 2005, s. 217-223;

29 E. Tov, Approaches towards Scripture Embraced by the Ancient Greek Translators, w: U. Mittmann-Richert, F. Avemarie, G. S. Oegema (red.), Der Mensch vor Gott, Neukirchener, Neukirchen-Vluyn 2003, s. 216. Na temat charakteru przekładu Dwunastu Proroków zob. także B d'A XXIII.4-9, s. 92-93; G. E. Howard, The Twelve Prophets. To the Reader, w: NETS, s. 777-780; J.M. Dines, The Minor Prophets, s. 440 oraz 442-444. Por. także: G. Sgargi, Gioele-Amos-Abdia: Versione ufficiale italiana confrontata con ebraico masoretico, greco dei Settanta, siriaco della Peshitta, latino della Vulgata, Biblia/Comunità di Monteveglio. AT 32-34, Edizioni Dehoniane Bologna, Bologna 1998. 


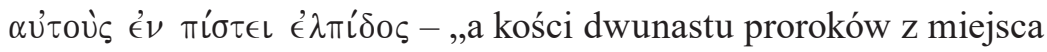
ich $^{30}$ niech wypuszczą pędy, pocieszyli bowiem Jakuba i wybawili go niezawodną nadzieją"). Niektórzy, jak G. J. Brook, uważają, że Księga Dwunastu Proroków jest traktowana jako całość dopiero od momentu jej tłumaczenia na język grecki w Aleksandrii (i że takie ich postrzeganie mogło być opinią środowiska Żydów aleksandryjskich, niekoniecznie podzielaną w Jerozolimie), ${ }^{31}$ jednak bez wątpienia w greckiej wersji księgi tego zbioru mają nie tylko wspólne pochodzenie, ale i charakter.

Argumenty zewnętrzne ukazują, że we wszystkich posiadanych przez nas rękopisach księgi Dwunastu Proroków są traktowane razem (zob. dalej); już Kodeks Watykański (najstarszy rękopis zawierający pełen tekst Dwunastu Proroków ${ }^{32}$ ) ma na końcu każdej księgi zbioru numerację od 1 do 12, zaznaczając kolejno poszczególne księgi, ale sugerując jednocześnie, że są one jednością. ${ }^{33}$ Pozostałe najstarsze greckie rękopisy (wyliczone skrupulatnie przez J. Zieglera w wydaniu krytycznym; ${ }^{34}$ zob. także dalej) traktują je również jako całość.

Nie przeszkadza to jednocześnie ukazywać charakterystycznych interpretacji, które dokonały się na poziomie poszczególnych ksiąg, zwłaszcza o tak ważnej tematyce jak Księga Abdiasza. Jej przekład, dokonany na obczyźnie, miał wyrażać i umacniać stosunek Izraelitów do sąsiadów, zarazem aktualizując go do sytuacji okresu

30 BT mówi o ,,ich grobie”.

31 G. J. Brooke, The Twelve Minor Prophets and the Dead Sea Scrolls, w: A. Lemaire (red.), Congress Volume Leiden 2004, Brill, Leiden 2006, s. 19-44 (zwł. s. 33); por. także: M. Beck, Das Dodekapropheton als Anthologie, Zeitschrift für die Alttestamentliche Wissenschaft 118/2006, s. 558-583.

32 Por. J. M. Dines, The Minor Prophets, s. 438.

33 W. E. Glenny, Hosea. A Commentary Based on Hosea in Codex Vaticanus, Leiden-Boston 2013, s. 1. Kodeks B można skonsultować także na niedawno utworzonej stronie internetowej ze zdigitalizowanymi rękopisami ze zbiorów Biblioteki Watykańskiej (Dwunastu Proroków od numeru karty 945; Księga Abdiasza to karty 972-973): http://digi.vatlib.it/view/MSS_Vat.gr.1209 (dostęp: 14 II 2020).

34 J. Ziegler (red.), Septuaginta. Vetus Testamentum Graecum. Auctoritate Academiae Scientiarum Gottingensis editum, t. XIII: Duodecim prophetae, Vandenhoeck \& Ruprecht, s. 7-119 (zaś opracowanie Księgi Abdiasza, s. 239-243). 
hellenistycznego: Edomici staną się w greckim tłumaczeniu księgi nie tylko symbolem wroga z przeszłości, ale obrazem wszelkich aktualnych wrogów Izraela. To właśnie z tego powodu LXXAbd

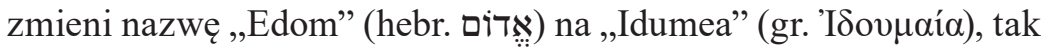
jak wówczas nazywano już krainę będącą wcześniej w posiadaniu Edomitów, bohaterów hebrajskiej Księgi Abdiasza.

Nie jest łatwo ustalić dokładną datację przekładu zbioru Dwunastu Proroków w LXX. ${ }^{35}$ Terminem najpóźniejszym jest powstanie greckiej Księgi Syracydesa - II w. przed Chr. - wspominającej Dwunastu Proroków, zaś najwcześniejszym jest przekład Tory dokonany w III w. przed Chr. (jako pierwszy przekład grecki ksiąg hebrajskich). Akurat analiza Księgi Abdiasza w jej greckiej wersji mogłaby ułatwić ustalenie datacji całego zbioru: może w tym pomóc porównanie LXXAbd z tekstem Księgi Jeremiasza, z którym porównywany jest przede wszystkim tekst hebrajski.

\section{LXXAbd a LXXJr 29,8-16 (oraz 17-22)}

Synoptycznego porównania tekstów hebrajskich Ksiąg: Abdiasza i Jeremiasza dokonywało wielu badaczy. ${ }^{36}$ Największe podobieństwo według nich wykazuje Księga Abdiasza do Jr 49,7-16, a także (mniej) do Jr 49,17-22 (oba teksty w LXX według numeracji greckiej

35 Zob. omówienie tego tematu w: B. Strzałkowska, Księga Ozeasza w Septuuagincie, s. 100-101.

36 Zob. P. Weimar, Obadja. Eine redaktionskritische Analyse, Biblische Notizen 27/1985, s. 35-99; G. S. Ogden, Prophetic Oracles Against Foreign Nations and Psalms of Communal Lament: The Relationship of Psalm 137 to Jeremiah 49:7-22 and Obadiah, Journal for the Study of the Old Testament 24/1982, s. 89-97; B. Dicou, Edom, Israel's Brother and Antagonist: The Role of Edom in Biblical Prophecy and Story, s. 58-69; zob. także opracowania tego tematu w: W. Rudolph, Joel - Amos - Obadja - Jona, Kommentar zum Alten Testament XIII/2, Gere Mohn, Gütersloh 1971; A. Deissler, Zwölf Propheten II: Obadja, Jona, Micha, Nahum, Habakuk, NEB.AT 8, Echter, Würzburg 1984; B. Hartberger, , An den Wassern von Babylon...”. Psalm 137 auf dem Hintergrund von Jeremia 51, der biblischen Edom-Traditionen und babylonischer Originalquellen; M. A. Sweeney, The Twelve Prophets. Volume one: Hosea, Joel, Amos, Obadiah, Jonah, s. 281-285. Por. także: E. Zenger, Il libro dei Dodici profeti, s. 890. 
podawanej za J. Zieglerem ${ }^{37}$ to LXXJr 29,8-16 oraz LXXJr 29,17-23). Niektórzy uważali nawet, że proroctwo Abdiasza powtarza niemal w całości fragment z Księgi Jeremiasza. ${ }^{38}$ Jeremiasz w swym tekście mówi właśnie o Edomitach jako o symbolu wrogości wobec Izraela. W Księdze Abdiasza tekst ten jest rozwinięty i podany w nieco odmiennej kolejności wierszy, ${ }^{39}$ a podobieństwo jest wyraźnie zwłaszcza w pierwszych sześciu wersetach Księgi Jeremiasza. Odpowiada im pierwsze sześć wersetów Księgi Abdiasza, a w zasadzie: czterem pierwszym wersetom Abdiasza (LXXAbd 1-4) odpowiadają wersety LXXJr 29,15-17 (czyli hebr. 49,14-16) a wersetom LXXAbd 5-6, odpowiadają wersety LXXJr 29,10-11. ${ }^{40}$ G. S. Ogden, badając tekst hebrajski obu ksiąg, stwierdził, że w obu tekstach można znaleźć odpowiedź na pytanie, które psalmista zadaje Bogu w Ps 136 [137], 7, by Ten przypomniał sobie o Edomie, jednak odpowiedź różna w obu księgach, powstała, jak się zdaje, w różnych okolicznościach. ${ }^{41}$

Badając tekst grecki Ksiegi Abdiasza, można zadać pytanie: Czy przekład w LXX mógł pozostawać pod wpływem Księgi Jeremiasza, zwłaszcza w jej greckim przekładzie? I czy można dostrzec w nich jakieś wzajemne (lub jednostronne) wpływy?

$\mathrm{Na}$ to pytanie odpowiadają analizy owych 6 wersetów LXXAbd. W jednych przypadkach, jak np. LXXAbd 1 i LXXJr 49,14, wydaje się, że przekład grecki Abdiasza mógłby być dostosowaniem do istniejącego już - przekładu greckiego Księgi Jeremiasza. ${ }^{42}$ Niestety,

37 Taka numeracja odpowiada także tej zaprezentowanej przez H.B. Swetego; inną prezentuje A. Rahlfs, według którego wersety, o których mowa to: LXXJr 30,8-16.17-23.

38 Por. B d'A XXIII.4-9, s. 89 oraz 90-91.

39 Por. tamże, s. 90-91.

40 Tamże, s. 90.

${ }^{41}$ Tamże, s. 90-91; por. G. S. Ogden, Prophetic Oracles against Foreign Nations and Psalms of Communal Lament: The Relationship of Psalm 137 to Jeremiah 49:7-22 and Obadiah, s. 89-97.

42 A. Gelston (red.), The Twelve Minor Prophets $=\urcorner$ ש ica Quinta Editione cum Apparatu Critico Novis Curis Elaborato, t. 13, Deustsche Bibelgesellschaft, Stuttgart 2010 s. 57 i komentarz: s. 89* (dalej BHQ). 
w pozostałych wersetach tych analogii nie ma, a opracowanie w serii La Bible d'Alexandrie wylicza pewne wybory leksykalne w obu greckich przekładach (LXXAbd i LXXJr) omawianych wersetów, ukazując, że - przekładając ich podobny tekst hebrajski - tłumacze używali jednak różnej terminologii. ${ }^{43}$ Przez te konkretne i różnorodne wybory leksykalne bardzo trudno jednoznacznie udowodnić ów możliwy wpływ greckich ksiąg na siebie.

\section{Struktura, tekst i przekład LXXAbd}

Struktura hebrajskiej Księgi Abdiasza, mimo że księga jest bardzo krótka, była przedmiotem licznych dyskusji ${ }^{44}$. Zazwyczaj badacze dzielili ją na 2 lub 3 części. Po zapowiadającym treść orędzia tytule księgi $(1,1)$ E. Zenger widział dwie następujące po sobie części: ww. 2-15 (obwieszczenie sądu nad Edomem) i ww. 16-21 (zapowiedź zbawienia na Syjonie i dla całego Izraela), w których dostrzegał mniejsze jednostki, z podsumowaniem w ww. 15 oraz $21 .{ }^{45}$ M. A. Sweeney dzieli księgę na dwie części: ww. 1-7 (wezwanie do ukarania Edomitów) oraz ww. 8-21 (prorocka zapowiedź sądu nad Edomem). ${ }^{46}$ Inni dzielili tekst na 3 części: ww.1-7 (gdzie ukazana jest pycha Edomu); ww. 8-15 (obrazująca wrogość Edomu względem Izraela) oraz ww. 16-21 (pokazujące zniszczenie Edomu, tryumf Boga na Syjonie i wybawienie Izraela). ${ }^{47}$

\footnotetext{
43 B d'A XXIII.4-9, s. 91.

44 Na temat struktury tekstu Abd zob. P. Weimar, Obadja: Eine redaktionskritische Analyse, Biblische Notizen 27/1985, s. 35-99; Th. Lescow, Die Komposition des Buches Obadja, Zeitschrift für die alttestamentliche Wissenschaft, 111/1999, s. 380-398; J. Renkema, The Literary Structure of Obadiah, w: C. A. M. Korpel (red.), Delimitation Criticism, Royal Van Gorcum, Assen 2000, s. 230-276; E. Assis, Structure, redaction and significance in the prophecy of Obadiah, Journal for the Study of the Old Testament 39(2014) nr 2, s. 209-221; M. Richelle, La structure littéraire du livre d'Abdias, Biblische Notizen 169/2016, s. 27-45.

45 E. Zenger, Il libro dei Dodici profeti, s. 887-888.

46 M. A. Sweeney, The Twelve Prophets. Volume one: Hosea, Joel, Amos, Obadiah, Jonah, s. 288-298.

47 Za V. Salanga, Księga Abdiasza, s. 1021.
} 
Tekst LXXAbd w dostępnych kodeksach i rękopisach zaprezentowany jest jako ciągły (scriptio continua), jednak z zaznaczeniem przerwy (tak robi Kodeks Watykański) przed w. 11 (zaznaczającym powrót z przeszłości) i w. 17 (wprowadzającym temat zbawienia); w konsekwencji tekst grecki można podzielić na 3 części. ${ }^{48}$ Tak robią wszystkie najważniejsze wydania krytyczne, na podstawie analizy treści księgi: H.B. Swete (odzwierciedlając lekcje Kodeksu Watykańskiego; ${ }^{49}$ za takim podziałem - choć bez śródtytułów - idzie także R. Popowski ${ }^{50}$ ); zaś A. Rahlfs ${ }^{51}$ i J. Ziegler ${ }^{52}$ - wyróżniają w LXXAbd 3 części, ale podzielone w następujący sposób:

- ww. 1-10: sąd Boży i zniszczenie Idumei (w miejsce hebr. Edomu) za niewierność względem Jakuba;

- ww. 11-16: sąd Boży który przyjdzie na Idumeę i inne narody;

- ww. 17-21: zbawienie na Syjonie, nowe założenie królestwa Pańskiego i zbawienie Izraela.

Widać w takiej strukturze jasny przekaz - zniszczenie Idumei (Edomu) za niewierność względem narodu wybranego - jest wypełnieniem sprawiedliwości Bożej nad światem, której elementem zarazem jest zbawienie Izraela, odnowienie jego królestwa, które identyfikowane jest w LXXAbd z królestwem samego Boga. Taki podział (wraz ze śródtytułami) przyjmuje opracowanie w serii La Bible d'Alexandrie. ${ }^{53}$

48 B d'A XXIII.4-9, s. 87-88.

49 H. B. Swete (red.), The Old Testament in Greek According to the Septuagint, t. III, The University Press, Cambridge $1922^{3}$.

50 R. Popowski (tłum. i oprac.), Septuaginta, czyli Biblia Starego Testamentu wraz z księgami deuterokanonicznymi i apokryfami, Prymasowska Seria Biblijna 37, Oficyna Wydawnicza „Vocatio”, Warszawa 2013 (Księga Abdiasza, s. 13291330) (dalej: Popowski).

51 A. Rahlfs, R. Hanhart (red.), Septuaginta. Id est Vetus Testamentum graece iuxta LXX interpretes, Deutsche Bibelgessellschaft, Stuttgart 2006.

52 J. Ziegler (red.), Septuaginta. Vetus Testamentum Graecum, t. XIII: Duodecim prophetae (Księga Abdiasza, s. 239-243).

53 Zob. B d'A XXIII.4-9, s. 87-88 oraz 98-113. 
Nieco inaczej dzielą tekst LXXAbd pozostałe współczesne tłumaczenia księgi z języka greckiego (choć oparte na tych samych wydaniach krytycznych). Przede wszystkim wydzielają dwie jednostki w samym tylko w. 1 (dzieląc go na la i lb; tak robi La Bible d'Alexandrie, NETS, Septuaginta Deutsch ${ }^{54}$ i La Biblia Griega:55 pierwszą część wersetu w brzmieniu: ő $\alpha \sigma \iota \varsigma$ A $\beta \delta ı v$ - „widzenie Abdiasza" - wydziela także R. Popowski ${ }^{56}$ ); a następnie interpretują poszczególne wersety wydzielając w księdze więcej części.

- NETS ${ }^{57}$ (bez śródtytułów): w. 1a; ww. 1b-4; ww. 5-9; ww. 10-14; ww. 15-21.

- SeptDeutch ${ }^{58}$ (wyróżniając śródtytuły): w. la (w przeciwieństwie

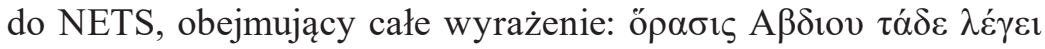

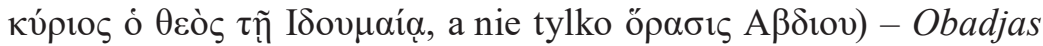
Vivion über Idumäa; w. 1,b - Gott ruft zum Kampf gegen die Völker auf; ww. 2-11 (w których wyróżnia się ww. 2-4; 5-7 oraz 8-11) - Die Schuld und das zukünftige Geschick Idumäas; ww. 12-16 - Am Tag des Herrn warden die Völker vernichtet warden und Idumäa Vergeltung erfahren; ww. 17-21 - Ganz Israel wird gerettet und erneuert.

- La Biblia Griega ${ }^{59}$ (bez śródtytułów): w. la (tylko ő $\rho \sigma \iota \varsigma$ A $\beta \delta ı$ เov); w. 1b; ww. 2-7; ww. 8-11; ww. 12-16; ww. 17-21.

54 W. Kraus, M. Karrer i in. (red.), Septuaginta Deutsch. Das griechische Alte Testament in deutcher Übersetzung, Stuttgart 2009 (Wprowadzenie do Dwunastu Proroków, s. 1165-1166 oraz s. 1195; przekład LXXAbd, s. 1195-1196) (dalej: SeptDeutsch); chodzi także o przygotowanym komentarz do tego niemieckiego przekładu: H. Schmoll, H. Utzschneider, Abdiu. Obadja, w: W. Kraus, M. Karrer $\mathrm{i}$ in. (red.), Septuaginta Deutsch. Erläuterungen und Kommentare zum gieschischen Alten Testament, t. II: Psalme bis Daniel, Stuttgart 2010, s. 2388-2393.

55 Libro de los Doce Profetas, w: N. Fernàndez Marcos, M. Victoria Spottorno Díaz-Caro (koord. wyd.), La Biblia Griega. Septuaginta IV. Libros proféticos. Biblioteca de Estudios Bíblicos 128, Salamanca 2015, s. 15-123 (Księga Abdiasza, s. 69-72) (dalej: BibliaGriega).

56 Por. Popowski, s. 1329-1330.

57 Por. NETS, s. 803-804.

58 Por. SeptDeutsch, s. 1195-1196; zob. także komentarz, H. Schmoll, H. Utzschneider, Abdiu. Obadja, w: SeptDeutsch, t. II: Psalme bis Daniel, s. 2388.

59 BibliaGriega, s. 69-72. 
Poniższa tabela prezentuje porównanie tekstu hebrajskiego (za $\mathrm{BHQ}^{60}$ ) i greckiego za wydaniem krytycznym z Göttingen ${ }^{61}$. Przekład jest jak najbardziej dosłowny, by ukazać charakterystykę obu tekstów - hebrajskiego i greckiego. Struktura tekstu, oparta na omówionych wcześniej, jest wynikiem własnej analizy LXXAbd, najbardziej jednak przypomina tę z SeptDeutsch.

\begin{tabular}{|c|c|c|c|}
\hline $\begin{array}{c}\text { LXX } \\
\text { (za Göttingen) }\end{array}$ & Przekład LXX & Przeklad TM & TM (za BHS) \\
\hline${ }^{1}$ ö $\rho \alpha \sigma \iota \mathrm{A} \beta \delta$ เov & Widzenie Abdiasza. & $\begin{array}{l}\text { Widzenie } \\
\text { Abdiasza. }\end{array}$ & 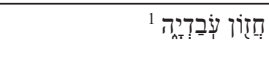 \\
\hline 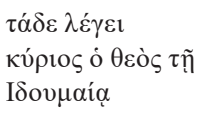 & $\begin{array}{l}\text { Tak mówi Pan Bóg } \\
\text { do Idumei. }\end{array}$ & $\begin{array}{l}\text { Tak mówi mój Pan } \\
\text { Bóg, do Edomu. }\end{array}$ & 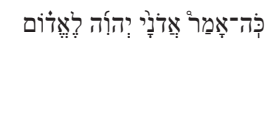 \\
\hline 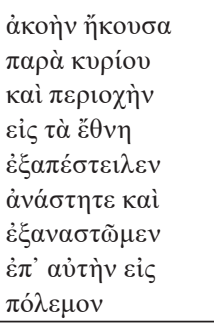 & $\begin{array}{l}\text { Wieść usłyszałem } \\
\text { od Pana i wiado- } \\
\text { mość do narodów } \\
\text { wysłał: „Wstańcie } \\
\text { i powstańmy prze- } \\
\text { ciw niej (= Idumei) } \\
\text { na wojnę” }\end{array}$ & $\begin{array}{l}\text { Wieść usłysze- } \\
\text { liśmy od Pana } \\
\text { i posłaniec wśród } \\
\text { narodów został } \\
\text { posłany: „Wstań- } \\
\text { cie! Powstańmy } \\
\text { przeciw niemu } \\
\text { (=Edomowi). Na } \\
\text { wojnę!” }\end{array}$ & 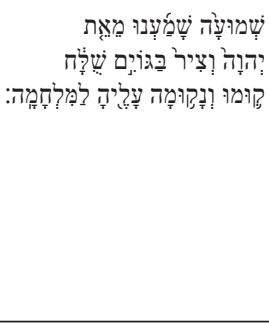 \\
\hline 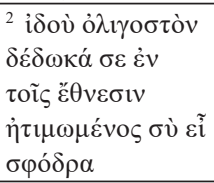 & $\begin{array}{l}\text { Oto bardzo małym } \\
\text { (masculinum!) } \\
\text { dałem ciebie między } \\
\text { narodami, jesteś } \\
\text { bardzo zhańbiony. }\end{array}$ & $\begin{array}{l}\text { Oto małym dałem } \\
\text { ciebie między na- } \\
\text { rodami, jesteś bar- } \\
\text { dzo wzgardzony. }\end{array}$ & 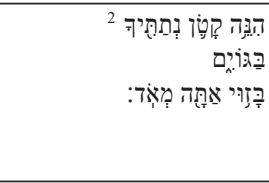 \\
\hline
\end{tabular}

60 BHQ.

${ }^{61}$ J. Ziegler (red.), Septuaginta. Vetus Testamentum Graecum, t. XIII: Duodecim prophetae, s. 239-243. 


\begin{tabular}{|c|c|c|c|}
\hline $\begin{array}{c}\text { LXX } \\
\text { (za Göttingen) }\end{array}$ & Przeklad LXX & Przekład TM & TM (za BHS) \\
\hline 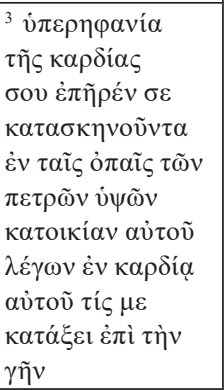 & $\begin{array}{l}\text { Pycha twego } \\
\text { serca wyniosła } \\
\text { cię, mieszkający } \\
\text { w rozpadlinach skal- } \\
\text { nych, podnoszący } \\
\text { swoje mieszkanie, } \\
\text { mówiący w swoim } \\
\text { sercu: „Któż mnie } \\
\text { strąci na ziemię?” }\end{array}$ & $\begin{array}{l}\text { Pycha twego serca } \\
\text { zwiodła cię, miesz- } \\
\text { kający w rozpad- } \\
\text { linach skalnych, } \\
\text { mieszkanie twoje } \\
\text { na wysokościach, } \\
\text { mówiący w swoim } \\
\text { sercu: „Któż mnie } \\
\text { strąci na ziemię?” }\end{array}$ & 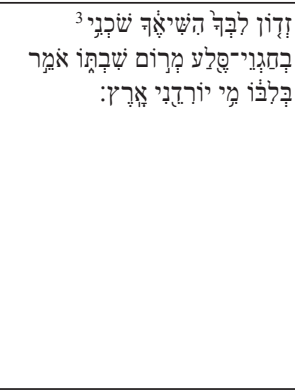 \\
\hline 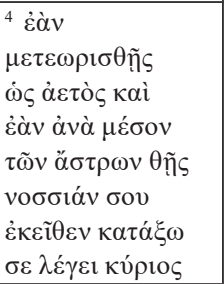 & $\begin{array}{l}\text { Choćbyś wzbił się } \\
\text { jak orzeł i choćbyś } \\
\text { między gwiaz- } \\
\text { dami umieścił swe } \\
\text { gniazdo, stamtąd } \\
\text { strącę ciebie, mówi } \\
\text { Pan. }\end{array}$ & $\begin{array}{l}\text { Choćbyś wzbił } \\
\text { się wysoko jak } \\
\text { orzeł i choćby } \\
\text { między gwiazdami } \\
\text { mieściło się swe } \\
\text { gniazdo, stamtąd } \\
\text { strącę ciebie, wy- } \\
\text { rocznia Pana. } \\
\end{array}$ & 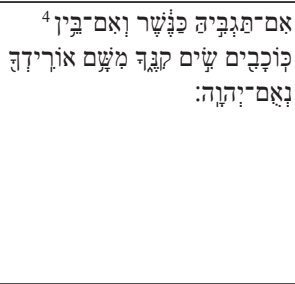 \\
\hline 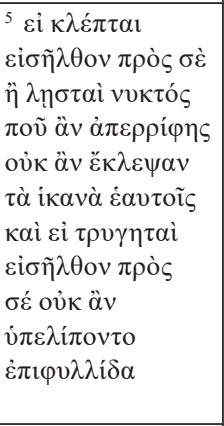 & $\begin{array}{l}\text { Jeśli złodzieje przy- } \\
\text { szliby do ciebie i ra- } \\
\text { busie nocą, gdzież } \\
\text { byłbyś wyrzucony? } \\
\text { Czyż nie zrabowa- } \\
\text { liby wystarczająco } \\
\text { dla nich? A jeśli zry- } \\
\text { wający winogrona } \\
\text { przyszliby do ciebie, } \\
\text { czyż nie pozostawi- } \\
\text { liby [tylko] jednego } \\
\text { winogrona? }\end{array}$ & \begin{tabular}{|l|} 
Jeśli złodzieje \\
przyjdą do ciebie, \\
jeśli rabusie nocą, \\
jakże będziesz \\
zniszczony! Czyż \\
nie zrabują wystar- \\
czająco? Jeśli zry- \\
wający winogrona \\
przyjdą do ciebie, \\
czyż zostawią \\
cokolwiek?
\end{tabular} & 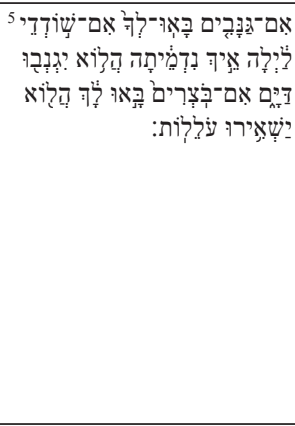 \\
\hline 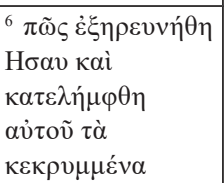 & $\begin{array}{l}\text { Jakże przeszukany } \\
\text { został Ezaw i od- } \\
\text { kryte zostały jego } \\
\text { kryjówki. }\end{array}$ & $\begin{array}{l}\text { Jakże przeszukaja } \\
\text { Ezawa, odkryja } \\
\text { jego ukryte skarby. }\end{array}$ & 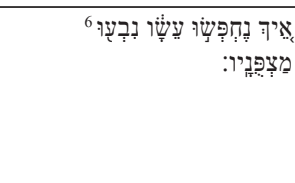 \\
\hline
\end{tabular}




\begin{tabular}{|c|c|c|c|}
\hline $\begin{array}{c}\text { LXX } \\
\text { (za Göttingen) }\end{array}$ & Przekład LXX & Przekład TM & TM (za BHS) \\
\hline 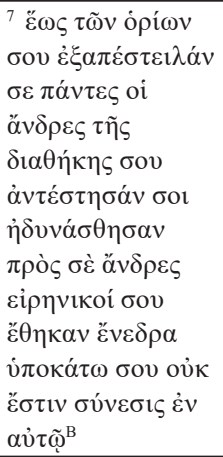 & $\begin{array}{l}\text { Aż do granic } \\
\text { twoich cię odesłali. } \\
\text { Wszyscy twoi } \\
\text { sprzymierzeńcy_ } \\
\text { stanęli przeciw to- } \\
\underline{\text { bie, przezwyciężyli }} \\
\text { cię twoi sojusz- } \\
\text { nicy } . \text { Umieścili } \\
\text { zasadzki pod tobą. } \\
\text { Nie ma [w] nich } \\
\text { zrozumienia. }\end{array}$ & $\begin{array}{l}\text { Aż do granicy } \\
\text { ścigać cię będą. } \\
\text { Wszyscy twoi } \\
\text { sprzymierzeńcy } \\
\text { cię zdradza, } \\
\text { przezwyciężą } \\
\text { cię twoi sojusz- } \\
\text { nicy. Twój chleb } \\
\text { [jedzacy] zastawią } \\
\text { sidła pod tobą. } \\
\text { "Nie ma w nim } \\
\text { zrozumienia". }\end{array}$ & 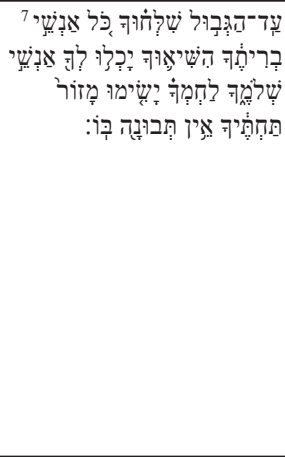 \\
\hline 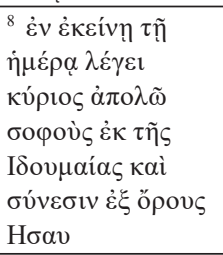 & $\begin{array}{l}\text { W owym dniu - } \\
\text { mówi Pan - zniszczę } \\
\text { (futurum!) mędrców } \\
\text { z Idumei i zrozumie- } \\
\text { nie z góry Ezawa. }\end{array}$ & $\begin{array}{l}\text { Czyż nie [stanie } \\
\text { się] w owym } \\
\text { dniu - wyrocznia } \\
\text { Pana - } \dot{z} e \text { wygubię } \\
\text { mędrców z Edomu } \\
\text { i zrozumienie } \\
\text { z góry Ezawa. }\end{array}$ & 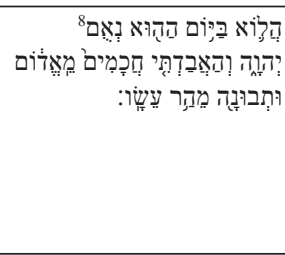 \\
\hline 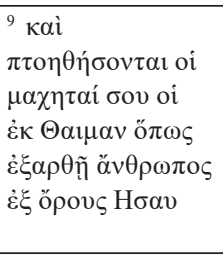 & $\begin{array}{l}\text { I będą przerażeni } \\
\text { wojownicy twoi, } \\
\text { ci z Temanu, aby } \\
\text { usunięty został czło- } \\
\text { wiek z góry Ezawa. }\end{array}$ & $\begin{array}{l}\text { I będą porażeni } \\
\text { twoi wojownicy, } \\
\text { Temanie, tak, iż } \\
\underline{\text { wycięty zostanie }} \\
\text { [każdy] mąż z góry } \\
\text { Ezawa z powodu } \\
\text { rzezi. }\end{array}$ & 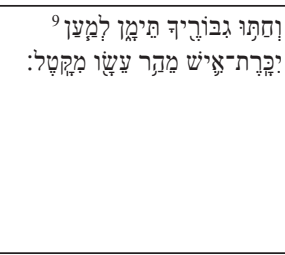 \\
\hline 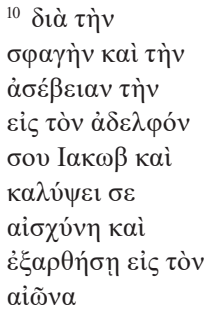 & $\begin{array}{l}\text { Z powodu rzezi } \\
\text { i niewierności } \\
\text { wobec brata twego, } \\
\text { Jakuba, okryje cię } \\
\text { hańba i zostaniesz- } \\
\text { usunięty na wieki. }\end{array}$ & $\begin{array}{l}\mathrm{Z} \text { powodu prze- } \\
\text { mocy [wobec] } \\
\text { brata twego, } \\
\text { Jakuba okryje cię } \\
\text { hańba i zostaniesz } \\
\text { wycięty na wieki. }\end{array}$ & 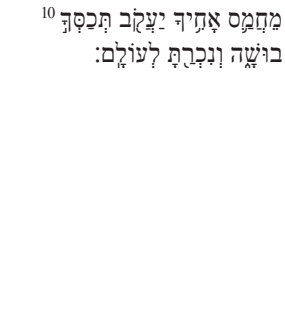 \\
\hline
\end{tabular}




\begin{tabular}{|c|c|c|c|}
\hline $\begin{array}{c}\text { LXX } \\
\text { (za Göttingen) }\end{array}$ & Przekład LXX & Przeklad TM & TM (za BHS) \\
\hline 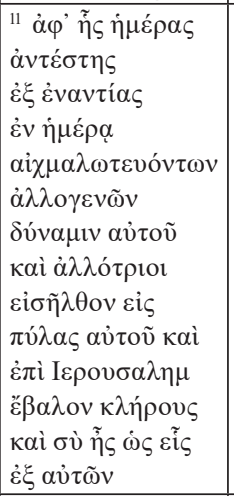 & $\begin{array}{l}\text { Od tego dnia, } \\
\text { w którym stanąłeś } \\
\text { w opozycji, w dniu, } \\
\text { w którym obcy } \\
\text { brali w niewolę jego } \\
\text { siły, a cudzoziemcy } \\
\text { wchodzili w jego } \\
\text { bramy, a o Jerozo- } \\
\text { limę rzucali losy, } \\
\text { także ty byłeś jak } \\
\text { jeden z nich. }\end{array}$ & $\begin{array}{l}\text { W dniu, w którym } \\
\text { stanąłeś przeciw } \\
\text { niemu, w dniu, } \\
\text { w którym obcy } \\
\text { brali } \\
\text { w niewolę jego } \\
\text { armię, a cudzo- } \\
\text { ziemcy wchodzili } \\
\text { w jego bramy, } \\
\text { a o Jerozolimę } \\
\text { rzucali los, także } \\
\text { ty [byłeś] jak jeden } \\
\text { z nich. }\end{array}$ & 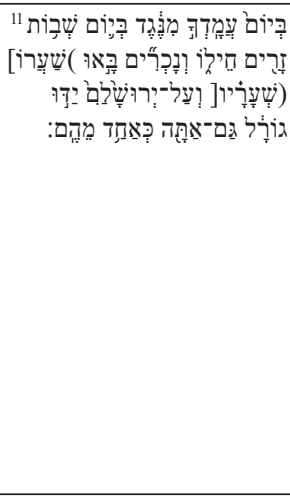 \\
\hline 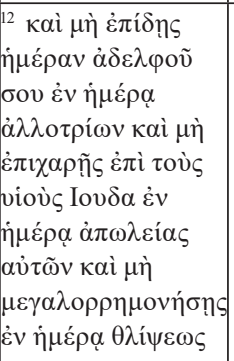 & $\begin{array}{l}\text { I nie patrz na dzień } \\
\text { twego brata w dniu } \\
\text { cudzoziemców. } \\
\text { I nie naśmiewaj się } \\
\text { z synów Judzkich } \\
\text { w dniu ich znisz- } \\
\text { czenia. I nie mów } \\
\text { zuchwale w dniu } \\
\text { niedoli! }\end{array}$ & \begin{tabular}{|l} 
I nie patrz na dzień \\
twego brata $\underline{\text { w dniu }}$ \\
jego nieszczęścia. \\
I nie naśmiewaj się \\
z synów Judzkich \\
w dniu ich znisz- \\
czenia. I nie mów \\
zuchwale w dniu \\
niedoli!
\end{tabular} & 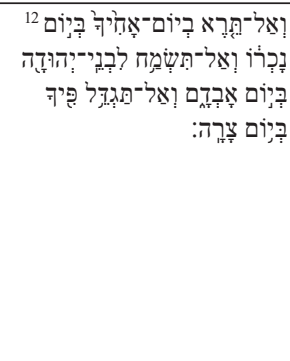 \\
\hline 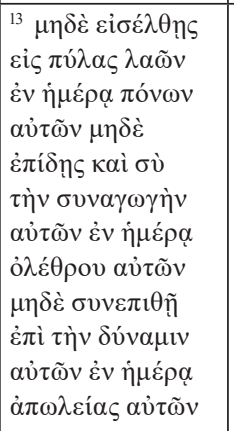 & $\begin{array}{l}\text { Nie wchodź } \\
\text { w bramy ludów } \\
\text { w dniu ich trudów, } \\
\text { ani nie patrz i ty na } \\
\underline{\text { ich zgromadzenie }} \\
\text { w dniu ich zniszcze- } \\
\underline{\text { nia. Ani nie dołaczaj }} \\
\underline{\text { się do ataku na jego }} \\
\text { wojsko w dniu ich } \\
\underline{\text { ruiny. }}\end{array}$ & \begin{tabular}{|l|} 
Nie wchodź \\
w bramę ludu \\
mego w dniu ich \\
kleski, nie patrz \\
także ty na jego \\
biedę w dniu jego \\
kleski. I nie wycia- \\
gaj [ręki] po jego \\
wojsko w dniu jego \\
klęski!
\end{tabular} & 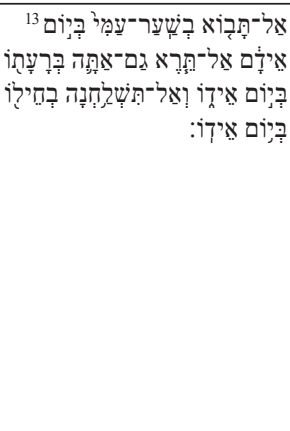 \\
\hline
\end{tabular}




\begin{tabular}{|c|c|c|c|}
\hline $\begin{array}{c}\text { LXX } \\
\text { (za Göttingen) }\end{array}$ & Przeklad LXX & Przeklad TM & TM (za BHS) \\
\hline 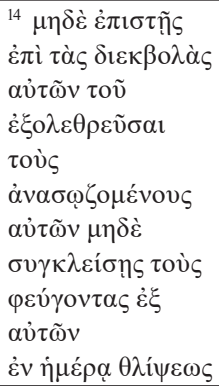 & $\begin{array}{l}\text { Ani nie stawaj na } \\
\text { przejściach ich, } \\
\text { aby wyciąć ich } \\
\text { ocalałych, ani nie } \\
\text { otaczaj uciekinierów } \\
\text { spośród nich w dniu } \\
\text { niedoli! }\end{array}$ & 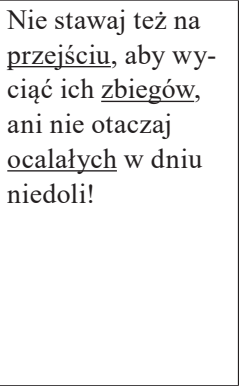 & 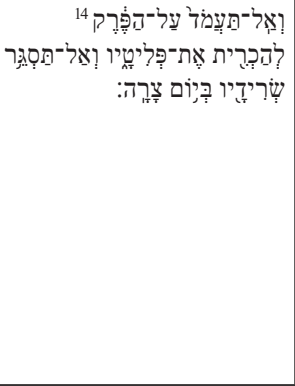 \\
\hline 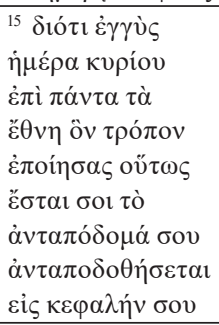 & $\begin{array}{l}\text { Ponieważ bliski } \\
\text { [jest] dzień Pański } \\
\text { nad wszystkimi } \\
\text { narodami! Tak } \\
\text { jak czyniłeś, tak } \\
\text { zostanie [uczynione] } \\
\text { tobie. Odpłata twoja } \\
\text { zostanie zwrócona } \\
\text { na twoją głowę. }\end{array}$ & $\begin{array}{l}\text { Bo bliski [jest] } \\
\text { dzień Pański nad } \\
\text { narodami! Jak } \\
\text { ty czyniłeś, tak } \\
\text { zostanie uczynione } \\
\text { tobie! Odpłata } \\
\text { twoja powróci na } \\
\text { twoją głowę. }\end{array}$ & 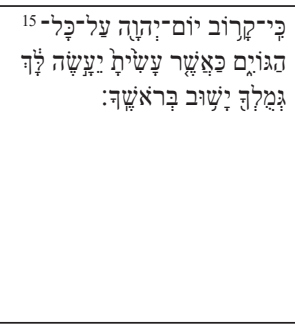 \\
\hline 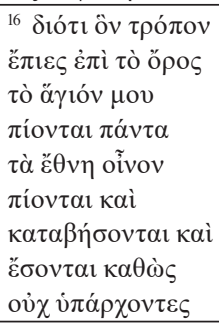 & $\begin{array}{l}\text { Ponieważ tak jak } \\
\text { piłeś na świętej } \\
\text { mej górze, [tak] } \\
\text { wypiją wszystkie } \\
\text { narody wino. Wypiją } \\
\text { i zejdą, i będąjakby } \\
\text { nie istnieli. }\end{array}$ & $\begin{array}{l}\text { Ponieważ jak } \\
\text { wy piliście na } \\
\text { górze świętej, tak } \\
\text { wypiją wszystkie } \\
\text { narody bez końca. } \\
\text { I wypiją, i połkną, } \\
\text { i będąjakby ich nie } \\
\text { było. }\end{array}$ & 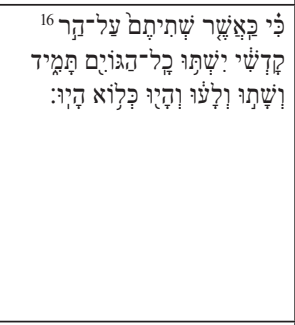 \\
\hline 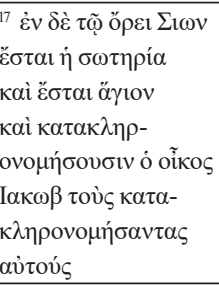 & $\begin{array}{l}\text { A na górze Syjon } \\
\text { będzie zbawienie } \\
\text { i będzie święta, } \\
\text { a dom Jakuba za- } \\
\text { właszczy tych, któ- } \\
\text { rzy jego [wcześniej] } \\
\text { zawłaszczyli. }\end{array}$ & $\begin{array}{l}\text { A na górze Syjon } \\
\text { będzie ocalenie }^{\mathrm{D}} \\
\text { i będzie święta, } \\
\text { a dom Jakuba wy- } \\
\text { właszczy tych, któ- } \\
\text { rzy go [wcześniej] } \\
\text { wywłaszczyli. }\end{array}$ & 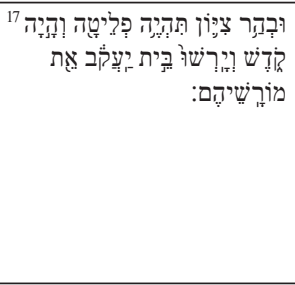 \\
\hline
\end{tabular}




\begin{tabular}{|c|c|c|c|}
\hline $\begin{array}{c}\text { LXX } \\
\text { (za Göttingen) }\end{array}$ & Przekład LXX & Przekład TM & TM (za BHS) \\
\hline 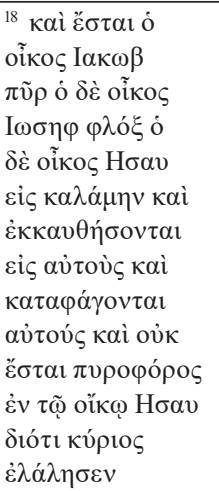 & 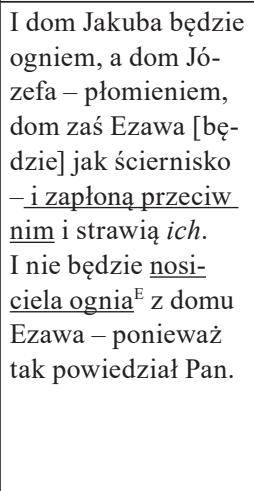 & \begin{tabular}{|l} 
I dom Jakuba \\
będzie ogniem, \\
a dom Józefa - pło- \\
mieniem, dom zaś \\
Ezawa [będzie] jak \\
ściernisko - spalą \\
je i strawią. I nie \\
będzie ocalałego \\
z domu Ezawa \\
- ponieważ tak \\
powiedział Pan.
\end{tabular} & 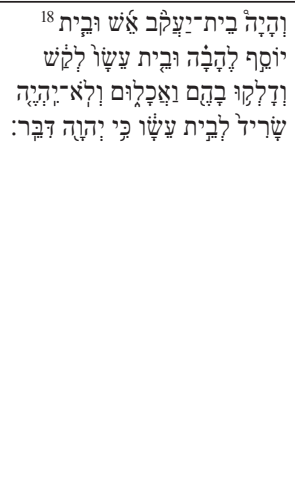 \\
\hline 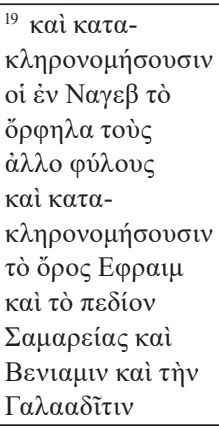 & $\begin{array}{l}\text { I zawłaszczą ci z Ne- } \\
\text { gewu }{ }^{\mathrm{F}} \text { górę Ezawa, } \\
\text { a ci z Szefeli }{ }^{\mathrm{G}}- \\
\text { obcych. I zawłasz- } \\
\text { oza góre Efraima } \\
\text { i równinę Samarii, } \\
\text { i Beniamina, } \\
\text { i Gileadu. }\end{array}$ & $\begin{array}{l}\text { I wywłaszczą } \\
\text { Negew, górę } \\
\text { Ezawa, i Szefelę, } \\
\text { [kraj] Filistynów. } \\
\text { I wywłaszcza } \\
\underline{\text { ziemię Efraima }} \\
\text { i ziemię Samarii, } \\
\text { i Beniamina razem } \\
\text { z Gileadem. }\end{array}$ & 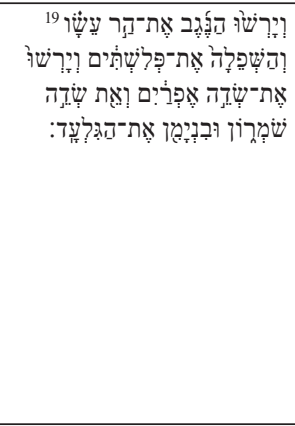 \\
\hline 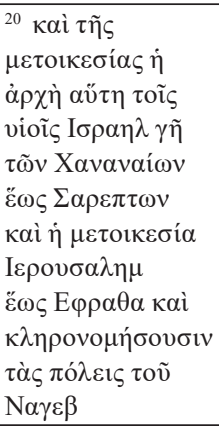 & $\begin{array}{l}\text { I początek ich } \\
\text { migracji [jest taki]: } \\
\text { synowie Izraela } \\
\text { [posiądą] ziemię } \\
\text { Kananejczyków } \\
\text { (Fenicjan?) aż do } \\
\text { Sarepty, a wygna- } \\
\text { nie (w znaczeniu } \\
\text { diaspory) z Jerozo- } \\
\text { limy - aż do Efrata, } \\
\text { i zawłaszczą miasta } \\
\text { Negevu }{ }^{\mathrm{H}} \text {. }\end{array}$ & $\begin{array}{l}\text { A wygnaniec } \\
\text { tej armii synów } \\
\text { Izraela [posiądzie] } \\
\text { Kananejczyj- } \\
\text { ków (Fenicjan?) } \\
\text { aż do Sarepty, } \\
\text { wygnaniec zaś } \\
\text { z Jerozolimy, } \\
\text { który [przebywa] } \\
\underline{\text { w Sfarad posiądzie }} \\
\text { miasta Negewu. }\end{array}$ & 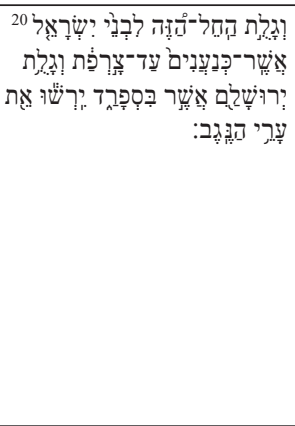 \\
\hline
\end{tabular}




\begin{tabular}{|c|c|c|c|}
\hline $\begin{array}{c}\text { LXX } \\
\text { (za Göttingen) } \\
\end{array}$ & Przeklad LXX & Przekład TM & TM (za BHS) \\
\hline 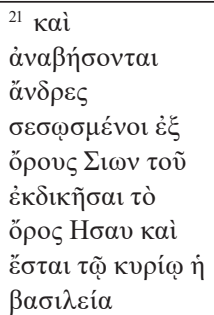 & $\begin{array}{l}\text { I mężowie ocaleni } \\
\text { wejdą na górę Syjon, } \\
\text { by ukarać górę } \\
\text { Ezawa, a królestwo } \\
\text { będzie [neleżeć do] } \\
\underline{\text { Pana! }}\end{array}$ & $\begin{array}{l}\text { I wyzwoliciele } \\
\text { wejdą na górę } \\
\text { Syjon, by osądzić } \\
\text { górę Ezawa.I I na- } \\
\text { stanie królowanie } \\
\text { Pana! }\end{array}$ & 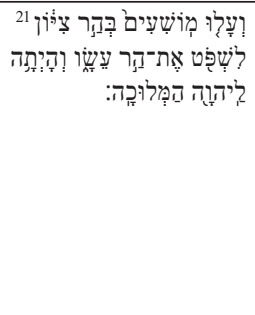 \\
\hline
\end{tabular}

A B d'A XXIII.4-9, s. 100-102: „Si des voleurs avaient pénétré chez toi, ou des brigands de nuit, où aurais-tu été précipité? N'auraient-ils pas volé leur content? Et si des vendangeurs avaient pénétré chez toi, n'auraient-ils pas laissé juste un grapillon?”; NETS: „If thieves came to you, or robbers by night, where would you be cast aside? Would they not steal what is sufficient for themselves? And if grape gatherers came to you would they not leave gleanings"; BibliaGriega: ,Si unos ladrones hubieran llegado a ti o salteadores de noche, ¿dónde habrías sido arrojado? ¿No habrían robado lo suficiente para sí mismos? Y si unos vendimiadores huberian llegado a ti, ¿no habrían dejado una rebusca?”; SeptDeutsch: „Wenn Diebe zu dir eingedrungen wären oder Räuber des Nachts, wohin wärest du dann geworfen worden! Nicht wahr - sie hätten gestohlen was für sie brauchbar war? Und wenn Traubenschnitter zu dir gekommen wären, hätten sie nicht (nur) eine Nachlese übrig gelassen?”; Popowski: ,Jeśli wtargną do ciebie złodzieje lub grabieżcy nocą, gdzie z tym się ukryjesz? Czyż nie zagarną sobie, ile zechcą? Lub jeśli szabrownicy winnic wedrą się do ciebie, czy pozostawią ci jakieś resztki?".

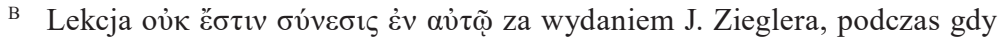
A. Rahlfs i H.B. Swete, za Kodeksem B, S (i innymi mniej ważnymi świadkami

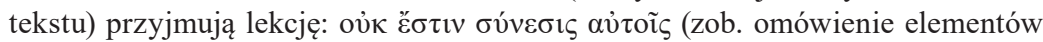
krytyki tekstualnej)

c Dosł. „ludzie twego pokoju” (przekład dosłowny idiomu hebrajskiego; zob. omówienie elementów krytyki tekstualnej).

D Także: „ucieczka”.

E SeptDeutsch: „Fackelträger”; NETS, BHQ: „firebearer”; B d'A XXIII.4-9: „porte-feu”; - użyte tu w sensie przenośnym jako „ocalały” (zob. analizę tego wersetu poniżej).

F Dosł. Nageb.

G Dosł. Sefela.

н Dosł. Nagebu. 


\section{Elementy krytyki tekstualnej i analiza LXXAbd}

Księga Abdiasza (jako część zbioru Dwunastu Proroków) została odnaleziona $\mathrm{w}$ wersji greckiej w kilku ważnych, dawnych świadkach tekstu i w wielu mniej istotnych. Wyliczają je dokładnie wydania krytyczne tekstu, zwłaszcza tom autorstwa J. Zieglera z serii z Göttingen ${ }^{62}$ (ale i inne, bardziej podręczne, wydania krytyczne: A. Rahlfs, ${ }^{63} \mathrm{H}$. B. Swete ${ }^{64}$ ). Nie wszystkie odnalezione rękopisy i posiadane obecnie ważne kodeksy tzw. Proroków Mniejszych, zawierają Księgę Abdiasza, inne zawierają jej fragmenty nie zawsze w dobrym stanie, z rozmaitymi brakami lub przepracowaniami. Dlatego warto wymienić najważniejszych świadków tekstu LXXAbd.

Najstarszym pełnym tekstem LXXAbd pozostaje Kodeks Watykański (B) z IV w., Kodeks Synaicki (S) z IV w. (zwój nie zawiera ksiąg: Ozeasza, Amosa i Micheasza, ale zawiera Księgę Abdiasza jednak z powodu tych dużych braków Kodeks ten postrzegany jest jako mniej istotny w przypadku zbioru Dwunastu Proroków ${ }^{65}$ ), Kodeks Aleksandryjski (A) z V w. (zawierający wprawdzie rozmaite wyjaśnienia i harmonizacje, ale przechowujący stare lekcje tekstu $\left.{ }^{66}\right)$, a także Kodeks Marchalianus (Q) z VI/VII w. (przechowywany w Bibliotece Watykańskiej, jako grecki kodeks 2125). ${ }^{67}$

Duże fragmenty LXXAbd zawiera uważany za najstarszy do czasu odkryć w okolicach Morza Martwego papirus zawierający Księgę Dwunastu Proroków - Kodeks Freer, in. Waszyngtoński V

${ }^{62}$ J. Ziegler (red.), Septuaginta. Vetus Testamentum Graecum, t. XIII: Duodecim prophetae.

${ }_{63}$ A. Rahlfs, R. Hanhart (red.), Septuaginta. Id est Vetus Testamentum graece, ad loc.

${ }^{64}$ H. B. Swete (red.), The Old Testament in Greek according to the Septuagint, t. III, ad loc.

65 J. M. Dines, The Minor Prophets, s. 438.

66 Tamże.

${ }^{67}$ Offizielles Verzeichnis der Rahlfs-Sigeln. Herausgegeben vom Septuaginta-Unternehmen der Akademie der Wissenschaften zu Göttingen, Göttingen 2012, s. 1. 
(oznaczany jako: W), z III w., przechowywany w Waszyngtonie. Zawiera on mocno zniszczoną Księgę Ozeasza i początek Księgi Amosa oraz rozmaite większe fragmenty pozostałych ksiąg (w tym Abdiasza). ${ }^{6}$ Dla badań nad LXXAbd pozostaje najstarszym, choć niepełnym, źródłem tekstu.

Dla tekstu hebrajskiego najstarszym fragmentem Księgi Abdiasza (mocno niepełnym) pozostaje jeden ze zwojów Dwunastu Proroków odnalezionych w Qumran ${ }^{69}$ i nieco późniejszy z Wadi Murabba'at. ${ }^{70}$ Niestety, greckiej Księgi Dwunastu Proroków ani w Qumran, ani w Wadi Murabba'at nie odnaleziono. Odkryto natomiast zwój grecki Proroków Mniejszych w Nachal Chewer: 8HevXIIgr ${ }^{71}$ (oznaczane czasem jako $8 \mathrm{HevXII}^{\mathrm{a}}$ oraz $8 \mathrm{HevXII}^{\mathrm{b}}$, a w numeracji Rahlfsa nosi numer $\left.943^{72}\right)$. Ów grecki zwój pochodzi z okresu późnoptolemejskiego lub wczesnorzymskiego. ${ }^{73}$ Według redaktora tego tekstu, E. Tova, zwój, który zawiera grecki zbiór Dwunastu Proroków, został zapisany przez

68 Tamże. Na jego temat zob.także: H. A. Sanders, The Old Testament Manuscripts in the Freer Collection, London 1917.

${ }^{69}$ I choć kilka zwojów qumrańskich pretenduje do miana „zwoju Dwunastu Proroków" (problemy z tą klasyfikacją omawiał Ph. Guillaume, A Reconsiderations of Manuscripts Classified As Scrolls of the Twelve Prophets (XII), Journal of Hebrew Scriptures 7/2007, s. 1-12, opierając argumentację m.in. na tym, że tylko dwa ze zwojów qumrańskich mają więcej niż dwie księgi proroków mniejszych razem: 4QXIIc z ok. 75 r. przed Chr. oraz 4QXIIg z ok. 25 r. przed Chr.; por. tamże, s. 3-4), to fragmenty hebrajskiej Księgi Abdiasza znajdują się tylko w tym drugim: 4QXIIg, który w ogóle jest najpełniejszym z qumrańskich zwojów Dwunastu Proroków (zwój ten zawiera fragmenty 8 z 12 ksiąg wchodzących w skład zbioru; por. tamże).

70 Wadi Murabba'at 88, z ok. 10 r. po Chr.; por. Ph. Guillaume, A Reconsiderations of Manuscripts, s. 9.

71 Na jego temat zob. E. Tov, R. Kraft, P. J. Parsons (red.), The Greek Minor Prophets Scroll from Nahal Hever (HevXIIgr), Discoveries in the Judean Desert VIII, Clarendon Press, London-Oxford 1990.

72 Offizielles Verzeichnis der Rahlfs-Sigeln, s. 15.

73 Por. E. Tov, R. Kraft, P. J. Parsons (red.), The Greek Minor Prophets Scroll from Nahal Hever, s. 14. 
dwie różne osoby ${ }^{74}$ (nie wiadomo, czy były to dwie osoby przepisujące jeden zwój, czy mamy do czynienia z dwoma zwojami, ${ }^{75}$ dlatego wspomniana różnica w nazewnictwie) i zawiera fragmenty Ksiąg: Zachariasza $(8 \mathrm{HevXII}$ ) oraz Micheasza, Habakuka i Sofoniasza, i ew. Jonasza, Micheasza i Nahuma (8HevXII $\left.{ }^{\mathrm{a}}\right)$. Księga Abdiasza w tym zwoju (zwojach), niestety, nie zachowała się.

Z tego powodu najważniejszymi (i najstarszymi) świadkami tekstu LXXAbd pozostają wspomniane kodeksy majuskułowe: Watykański (B), Synaicki (S), Aleksandryjski (A), Freer (W) oraz Marchalianus (Q).

Pośród kodeksów minuskułowych (późniejszych) dla tekstu LXXAbd najważniejsze są kodeksy: ${ }^{76} 22$ (XI/XII w., Londyn, recenzja Lukiana); 26 (X w., Watykan, jako grecki kodeks 556); 36 (XI w., Watykan, jako grecki kodeks 347); 46 (XIII/XIV w., Paryż); 48 (X/ XI w. Watykan, jako grecki kodeks 1794, recenzja Lukiana); 51 (XI w., Florencja, recenzja Lukiana); 62 (XI w., Oxford, recenzja Lukiana); 68 (XV w., Wenecja); 86 (IX/X w., Watykan, jako grecki kodeks 549); 96 (XI w., Kopenhaga); 106 (XIV w., Ferrara); 122 (XV w., Wenecja); 130 (XII/XIII w., Wiedeń); 147 (XII w., Oxford, obok katen do ksiąg poetyckich także księgi prorockie); 198 (IX w., Paryż); 228 (XIII w., Watykan, jako grecki kodeks 1764, do 16 proroków, katena?); 231 (X/ XI w., Watykan, jako grecki kodeks 1670); 233 (X w., Watykan, jako grecki kodeks 2067); 239 (1046 r., Bolonia); 311 (XII w., Moskwa); 393 (VIII w. oraz przepisany w XIII w., Grottaferrata i Watykan); 407 (IX w., Jerozolima); 410 (XIII w., Jerozolima, Petersburg); 420 (1437 r., Londyn); 432 (X w., Amorgos); 449 (X./XI w., Mediolan); 456 (XI w., Messyna, Londyn, Mediolan, Oxford); 461 (XVI w., Meteory); 490 (XI w., Monachium); 501 (XV w., Norymberga); 534 (XI w., Paryż); 538 (XII w., Paryż); 544 (XI w., Paryż); 613 (XIII w., Patmos); 631 (XIV w., Praga); 667 (X. w. rescr., Watykan, jako grecki

74 Tamże; zob. także: D. Barthélemy, Les devanciers d.'Aquila, Vetus Testamentum Supplements 10, Brill, Leiden 1963, s. 167.

75 Ph. Guillaume, A Reconsiderations of Manuscripts, s. 5-8.

76 Za numeracją: Offizielles Verzeichnis der Rahlfs-Sigeln. 
kodeks 316; 710 (X. w., Synaj); 711 (XI w., Synaj); 719 (IX/X w., Turyn); 763 (XI w., Atos); 764 (XIII/XIV w., Atos); 770 (XII w., rękopis wybrakowany, Atos).

Ważne dla studium tekstu LXXAbd są kateny do Dwunastu Proroków (w tym do Abdiasza): ${ }^{77} 49$ (XI w., Florencja); 87 (X w., Watykan); 91 (XI w., Watykan, jako grecki kodeks 452); 97 (XII/XIII w., Watykan, jako greckie kodeksy 1153 i 1154); 240 (1285 r., Florencja); 310 (XIII w., Moskwa); 349 (XIII w., Bazylea); 398 (XIV w., Ateny); 568 (XIII w., Paryż); 575 (ekloga?, XIII w., Paryż).

Oprócz tego warto tekst grecki Księgi Abdiasza porównać z TM, tekstami hebrajskimi odnalezionymi w Qumran, Vul., Peš, Targ, a także recenzjami greckimi, zwłaszcza Aquili i Symmacha.

Najważniejsze elementy krytyki tekstualnej LXXAbd (z pominięciem zmian nieistotnych dla interpretacji) wyliczone są poniżej.

\section{Werset 1}

1. Imię Abdiasza, a w konsekwencji także tytuł księgi, w wersji greckiej ma dwa zasadnicze brzmienia w różnych rękopisach: ó $\rho \alpha \_\iota$

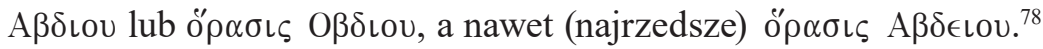
„Zgrecyzowaną" formę ö $\rho \alpha \sigma \varsigma$ A $\beta \delta\llcorner$ mają rękopisy: S, A, 22, $26,36,40,42,49,51,62,68,86,87,91,95,97,114,147,153,185,198$, $228,238,239,310,311$ oraz jest ona obecna w pismach Atanazego i Euzebiusza z Cezarei ${ }^{79}$ (zaś do tej formy kodeksy 86, 233, 534 oraz

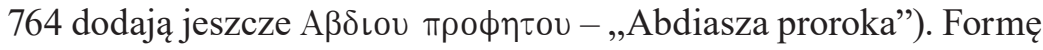

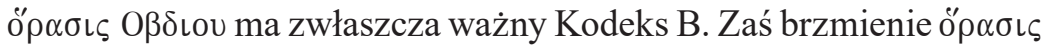
$\mathrm{A} \beta \delta \epsilon \iota \mathrm{u}$ jest obecne jako korekta w Kodeksie B, jako forma w kodeksie 251 oraz w pismach Cyryla Aleksandryjskiego. Dwa rękopisy

77 Za: tamże.

78 Zob. omówienie: H. Schmoll, H. Utzschneider, Abdiu. Obadja, w: SeptDeutsch, t. II: Psalme bis Daniel, s. 2388.

79 J. Ziegler (red.), Septuaginta. Vetus Testamentum Graecum, t. XIII: Duodecim prophetae, ad loc. 
z X/XI w. (o numeracji 48 i 763) dają prosty tytuł Abdias (w nom.). ${ }^{80}$ Żadna z wersji starożytnych nie tłumaczy imienia zgodnie z jego znaczeniem hebrajskim (,czciciel Jahwe”, „sługa Jahwe”), ale starają się oddać jego brzmienie.

2. LXX jako jedyna $\mathrm{z}$ wersji starożytnych zamienia obecną w TH, Vul, Peš, Targ., oraz w tekście Dwunastu Proroków odnale-

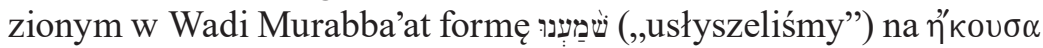
(,usłyszałem”). ${ }^{81}$ Mają tak wszystkie najważniejsze rękopisy greckie poza dwoma późnymi minuskułami $(62,538) .{ }^{82}$ Według wszelkiego prawdopodobieństwa zmiana ta jest dostosowaniem greckiego przekładu do tekstu Jr 49,14 ${ }^{83}$ (zob. omówienie relacji między oboma tekstami dalej). Zmiana ta jest tez próbą harmonizacji tekstu, który w tekście hebrajskim wersetu pierwszego ma kilka podmiotów. ${ }^{84}$

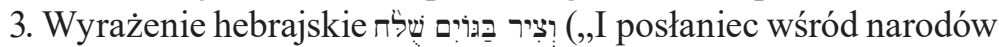
został wysłany"), obecne w takiej formie także w Targ., zostało prze-

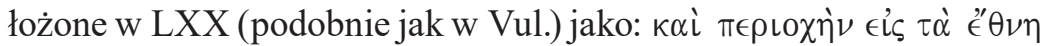

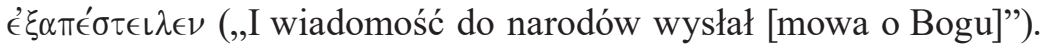
Zmiana ta, obecna we wszystkich rękopisach greckich Księgi Abdiasza (w rękopisach 233 i 710 przyjmuje jedynie analogiczną formę ape,steilen, zaś w rękopisach 130 i 613 formę $\left.\epsilon^{\prime} \xi \alpha \pi \epsilon ́ \sigma \tau \epsilon \nu \lambda \alpha\right),{ }^{85}$ wiąże się $\mathrm{z}$ innym odczytaniem tekstu hebrajskiego - konkretnie z inną jego wokalizacją: שִ של (,Został wysłany”) odczytano w tych wersjach jako שֵלח (,wysłał"), zaś drugi termin odczytano

80 B d'A XXIII.4-9, s. 85.

81 BHQ, s. 57 oraz s. 89*.

82 Zob. J. Ziegler (red.), Septuaginta. Vetus Testamentum Graecum, t. XIII: Duodecim prophetae, ad loc.

83 BHQ, s. 57 oraz s. 89*.

84 Na ten temat zob. B d'A XXIII.4-9, s. 98-99; Z tego powodu SeptDeutsch i niniejsze opracowanie wyróżnia niejako 3 części tego wersetu (zob. tabelę); SeptDeutsch, s. 1195.

85 Zob. J. Ziegler (red.), Septuaginta. Vetus Testamentum Graecum, t. XIII: Duodecim prophetae, ad loc.

${ }^{86}$ BHQ, s. 57 oraz s. 89*. 
jako dopełnienie, a nie podmiot tego zdania. ${ }^{87}$ Podobną zmianę mają zresztą także wersje Symm. i Aq., tylko że zamiast terminu $\pi \epsilon \rho \iota 0 \chi \eta$, używają one terminu: $\alpha^{\prime} \gamma \gamma \in \lambda i^{\prime} \alpha^{88}$. Natomiast Jr 29,15 (tekst analogiczny; według numeracji hebrajskiej 49,14) tłumaczy hebrajskie צִיר przez $\alpha \gamma \gamma \in \lambda$ os. W hebrajskim tekście Dwunastu Proroków odnalezionym w Wadi Murabba'at, a także w rękopisie Dwunastu Proroków odnalezionym w 4. grocie w Qumran $\left(4 \mathrm{QXII}^{\mathrm{g}}\right)$ ta konkretna lekcja, choć jest zachowana, nie jest wystarczająco wyraźna, by można ją było odczytać bez wątpliwości, ${ }^{89}$ a byłoby to pomocne w próbie odtworzenia historii tego tekstu.

4. Zamiana nazwy hebrajskiej „Edom” (אדוֹם) na „Idumea”

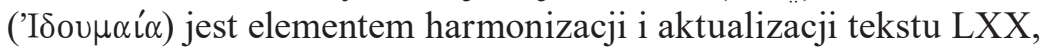
typowym dla Dwunastu Proroków (zob. na ten temat dalej paragraf dot. charakteru przekładu LXXAbd).

5. Obecna w LXX zmiana zaimka z męskiego ( אעליה) na żeński

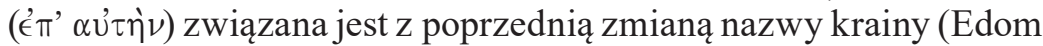
na Idumeę). Podobnie później uczyni Vul. Trzeba jednocześnie zaznaczyć, że w dalszych wersetach LXXAbd tłumacz nie będzie konsekwentny i już w w. 2 wróci do rodzaju męskiego. Zapewne z tego powodu w trzech rękopisach greckich $(46,86,711$ oraz u Teodoreta

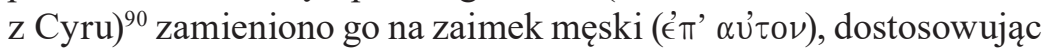
nie tylko do tekstu hebrajskiego, ale i do kolejnych wersetów greckich.

\section{Werset 2}

1. Rozpoczynająca zdanie partykuła הְִּ: (,oto”), przełożona w LXX typowo jako ioov. (,oto”), została pominięta w przekładzie greckim paralelnego tekstu LXX Jr 29,16 ${ }^{11}$ (według numeracji he-

87 Tamże.

${ }^{88}$ BHQ, s. 57; por. B d'A XXIII.4-9, s. 99.

89 BHQ, s. 57.

90 Zob. J. Ziegler (red.), Septuaginta. Vetus Testamentum Graecum, t. XIII: Duodecim prophetae, ad loc.

91 U A. Rahlfsa (A. Rahlfs, R. Hanhart/red./, Septuaginta. Id est Vetus Testamentum graece, ad loc.) numeracja: 30,9 . 
brajskiej 49,15). Partykuła ta pełni jednak ważną rolę stylistyczną w zdaniu, zwracając uwagę odbiorcy na ogłaszany Boży wyrok, a także wyjaśniając karę, która ma spaść na Edom (Idumeę). ${ }^{92}$ Partykuła ta pojawiająca się aż 56 razy w zbiorze Dwunastu Proroków i jest elementem typowego języka prorockiego, zarówno TH, jak i TG.

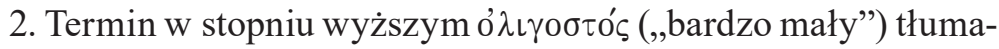
czy w LXXAbd hebrajski termin קט („,mały”). Bardziej dosłownie jest on oddany w analogicznym tekście LXXJr 29,16 (według numeracji hebrajskiej 49,15) jako $\mu$ ıкрò $\left(\right.$,małym [uczyniłem ciebie]”). ${ }^{93}$

\section{Werset 3}

1. Wyrażenie הִשִׁיאת (,zwiodła cię"), tak przełożone także w Peš i Targ., a także w wersjach Symm., Aq. i Teod., przetłumaczono inaczej w LXX: jako є̇ $\pi \hat{\rho} \rho \epsilon$ v $\sigma \epsilon$ (,wyniosła cię"), co jest wynikiem innego odczytania rdzenia נשיא jako. Podobnie odczytuje ten tekst Vul. ${ }^{94}$ Zwój z Wadi Murabba'at nie pomaga rozstrzygnąć tej kwestii, zaś greckie wersje Symm., Aq. i Teod., odczytujące ten rdzeń inaczej niż LXX, jako „zwieść” (jak TM), mogą być interpretacją, dostosowaniem tekstu do choćby znanego autorom tekstu Rdz 3,13 (gdzie pojawia się czasownik נשא w kontekście grzechu pierwszych rodziców). ${ }^{95}$

2. W LXX imiesłów ư $\psi \omega \nu$ (,podnoszący”) tłumaczy hebrajski rzeczownik מְרוֹם (,miejsce wysokie”, ,wysokości”). Bez wątpienia hebrajski rzeczownik w kontekście całego zdania był dość trudny do interpretacji, choć obecny w takiej formie także w zwoju z Wadi Murabba'at. Zmiana ta obecna w LXX wynikła zapewne z odczy-

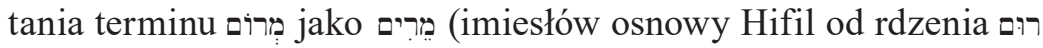
„wynosić”) ${ }^{96}$ i ma charakter ułatwiający odczytanie całego kontekstu

\footnotetext{
92 Por. B d'A XXIII.4-9, s. 99.

93 Por. tamże, s. 99-100.

94 BHQ, s. 57.

95 B d'A XXIII.4-9, s. 100.

96 Tamże.
} 
zdania i jest obecna także w Vul. (exaltantem). Z kolei tradycja targumiczna oraz Peš. mają tu zmianę syntaktyczną - dodają przyimek ב, całe wyrażenie: ברומיטא (,na wysokościach”) staje się bardziej zrozumiałe w kontekście całości zdania. ${ }^{97}$ Znaczenie tego wersetu interpretowano w sensie materialnym (jako trudno dostępny kraj) albo alegorycznie (jako pycha, wyniosłość; por. Teodor z Mopsuestii, Teodoret z Cyru, Cyryl Aleksandryjski). ${ }^{98}$

\section{Werset 4}

Czasownik שִים („mieściło się”), tak obecny w zwoju z Wadi Murabba'at, we wszystkich ważnych wersjach starożytnych: LXX, Vul., Peš., Targ. jest przełożony tak, jakby miał formę תשים (,umieścił"), co jest dostosowaniem tego czasownika do kontekstu. ${ }^{99} \mathrm{Co}$ ciekawe, w tej właśnie formie odnaleziono go także w hebrajskim fragmencie Księgi Abdiasza odnalezionym w Qumran (4QXII $\left.{ }^{\mathrm{g}}\right){ }^{100}$ starszym od TM i wersji z Muraba'at. Z tego powodu można byłoby uznać, że w starożytności istniały dwie formy hebrajskiego tekstu jedna stanowiąca podstawę TM i druga, która posłużyła m.in. tłumaczowi greckiemu w jego przekładzie. Jednak badania prowadzone nad rękopisami qumrańskimi w tym przypadku wskazują na możliwą korektę tekstu. Oryginalną lekcją 4QXII' miałaby być forma שים, natomiast $\Omega$ miało zostać dodane do tego czasownika później przez korektora. ${ }^{101}$ Forma obecna w TM mogła zostać tak ukształtowana pod wpływem tekstu z Lb 24,21. ${ }^{102}$ Zmiany zaś w LXX mają charakter gramatyczny harmonizacyjny.

\footnotetext{
97 BHQ, s. 89*.

98 B d'A XXIII.4-9, s. 100.

99 BHQ, s. 57; por. B d'A XXIII.4-9, s. 101.

${ }^{100}$ BHQ, s. 57 oraz s. 89*.

101 Tamże, s. 57.

102 Tamże, s. 89*; por. B d'A XXIII.4-9, s. 101.
} 


\section{Werset 5}

Całe zdanie w LXX jest dość trudne, złożone z przypuszczeń i pytań, najpewniej retorycznych, ukazujących to, co miałoby spotkać Edomitów (Idumejczyków). Jednak różnice między TH a LXX dotyczą nie krytyki tekstualnej, a interpretacji. W TH wszystkie zdania złożone na ten werset miały charakter zapowiedzi, tu mają nieco inny odcień znaczeniowy, choć treściowo są do siebie zbliżone. Zapewne z powodu tych trudności w przekładzie greckim pojawiły się zmiany względem $\mathrm{TH}$, mimo że rękopisy z rzadka różnią się między sobą $\mathrm{w}$ formach gramatycznych czasowników. ${ }^{103}$

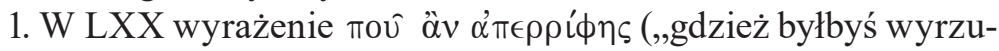

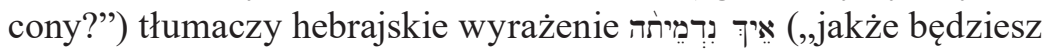
zniszczony!"). Greckie pytanie retoryczne (brzmiące tak samo we wszystkich dostępnych nam rękopisach) zastępuje hebrajskie zdanie emfatyczne, o nieco innym znaczeniu. Jedni przypuszczali, że tłumacz grecki odczytał błędnie hebrajskie $\neg$ jako $า$ (częsty błąd), uzyskując nowe znaczenie całego wyrażenia (podobny zabieg w Oz 10,7,, 104 a także w Oz 11,1 $(10,15) \cdot{ }^{105}$ Inni ukazywali, że kłopot z tym terminem hebrajskim miały inne tradycje, np. Targ. posiada w tym miejscu lek-

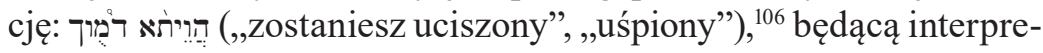
tacją thumacza (podobnie ma także wersja Symm.), zaś jeszcze inną tego typu interpretację zawiera Peš. oraz Vul. (quomodo conticuisses).

103 Por. R. Holmes, J. Parsons (red.), Vetus Testamneum Graecum cum Variis

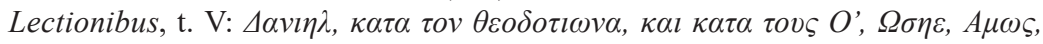

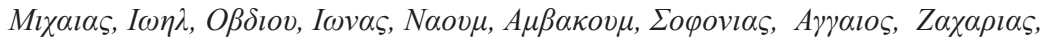

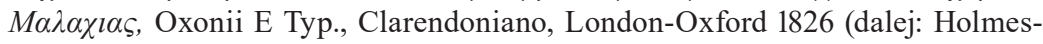
-Parsons), ad loc.; oraz: J. Ziegler (red.), Septuaginta. Vetus Testamentum Graecum, t. XIII: Duodecim prophetae, ad loc.

104 BHQ, s. 89*.

105 B d'A XXIII.4-9, s. 101. Na jego temat zob. A. Kaminka, Studien zur Septuaginta an der Hand der zwölf kleinen Prophetenbücher, s. 54, 247; por. także: E. Tov, On Pseudo-Variants Reflected in the Septuagint, Journal of Semitic Studies 20/1975, s. 172.

106 BHQ, s. 57 oraz B d'A XXIII.4-9, s. 101. 
Inni jeszcze zwracali uwagę na wieloznaczność samego terminu

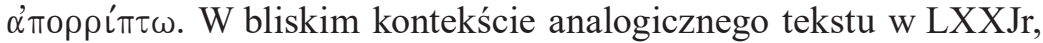
konkretnie w poprzedzającym go Jr 29,5 (według numeracji hebraj-

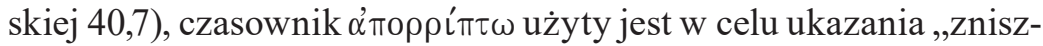
czenia” Aszkelonu, jego ,destrukcji”. Podobnie ideę zniszczenia widzi tu Aq. (wierny TH). Inni widzieli w LXXAbd 1,5 znaczenie „wyrzucenia” (co pasuje do kontekstu użycia tego słowa u Dwunastu Proroków, konkretnie w Jon 2,4). ${ }^{107}$ Wraz z pytaniem o miejsce (gr. noû) w omawianym tekście Księgi Abdiasza ten ostatni przekład wydaje się najbardziej właściwy: ,gdzież będziesz wyrzucony?”.

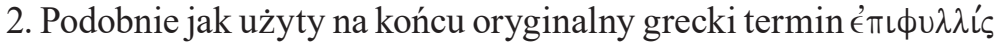
(„pozostałość”, ,jedno grono”, „,resztki z winorośli”) jest interpretacją hebrajskiego עלילוֹ (,resztki”, „,cokolwiek pozostałego [po czymś, z czegoś]'). Termin ten jest znany dobrze w grece klasycznej (m.in. u Arystofanesa ${ }^{108}$ ). Co ciekawe, w analogicznym tekście LXXJr 29,10 (według numeracji hebrajskiej 49,9) ten sam termin hebrajski עלל przełożony jest bardziej dosłownie przez gr. $\kappa \alpha \tau \alpha^{\prime} \lambda \in \iota \mu \mu \alpha$ („resztka”, ,pozostałość”), według tekstu przyjętego przez A. Rahlfsa (m.in.za rękopisami: B, S); lub też $\kappa \alpha \lambda \alpha \mu \epsilon ́ \mu \alpha \tau \alpha$ (,słoma”, ,ściernisko"), według tekstu przyjętego przez J. Zieglera (za rękopisami: A, Q, V, 46, 86, 110, 130, 233, 538, 544; taką lekcję mają też wersje koptyjskie, ormiańska, taka lekcja jest także obecna u Teodoreta z $\mathrm{Cyru}^{109}$ ).

\section{Werset 6}

1. Zmiana interpretacyjna obecna jest w obu czasownikach: chodzi o gramatyczną zmianę czasu w LXX - z przyszłego (w TH) na dokonany (podobnie będzie miała Vul.: scrutati sunt) Ezaw z przedmiotu stanie się podmiotem zdania (choć pasywnym). Tak mają wszystkie wersje (LXX, Vul., Peš., Targ.) poza TM, którego lekcję w przypadku

\footnotetext{
107 Tamże.

108 Tamże.

109 J. Ziegler (red.), Septuaginta. Vetus Testamentum Graecum, t. XIII: Duodecim prophetae, ad loc.
} 
obu czasowników poświadcza także rękopis z Wadi Muraba'at. ${ }^{110}$ Zmiana ma charakter harmonizujący i aktualizujący.

2. Użyty w LXX oryginalny termin $\alpha$ ư $\tau 0 \hat{v} \tau \dot{\alpha} \kappa \epsilon \kappa \rho u \mu \mu \epsilon^{\prime} \nu \alpha$ (,,jego

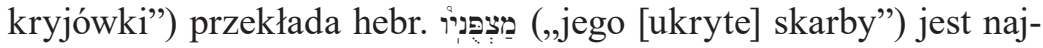
prawdopodobniej wynikiem nieznajomości leksykalnej tłumacza LXXAbd, podobną lekcję ma także Wulgata (abscondita eius). ${ }^{111}$

\section{Werset 7}

Ten werset na gruncie języka hebrajskiego doczekał się wielu interpretacji. ${ }^{112} \mathrm{~W}$ rezultacie jego niejednoznaczności (niektóry widzieli w nim crux interpretum), tłumacz grecki także musiał dokonać wyboru, przekładając jego sens.

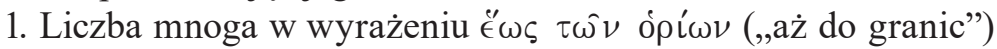

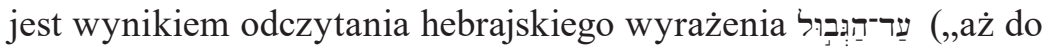
granicy”) jako liczby pojedynczej kolektywnej (o znaczeniu ,aż do granic"). ${ }^{113}$ Zmiana ta ma charakter harmonizujący i jest zmianą interpretacyjną. Do tego wiele rękopisów dodaje po wyrażeniu zaimek sou (,twoich”) - zob. W (+ 407, 410), A (+ 106, 26), $49(+764,613)$, 198, 233 (+710), 534, 544, podobnie jak wersje: koptyjska bohajrycka, etiopska, arabska oraz pisma Teodora z Mopsuestii i Cyryla Aleksandryjskiego. ${ }^{114}$

2. W czasownikach tego wersetu (,,ścigać”, ,wysłać”, „zdradzać”, „stanąć przeciw”, „przezwyciężyć”, „,zastawiać sidła, zasadzki”) w tekście greckim zastosowano zmianę czasu: z przyszłego (obecnego

110 BHQ, s. 57.

111 Por. tamże.

112 Por. P. K. McCarter, Obadiah 7 and the Fall of Edom, Bulletin of the American Schools of Oriental Research 220-221/1975-1976 (dec-febr), s. 87-91; G. I. Davies, A New Solution to a Crux in Obadiah 7, Vetus Testamentum 27/1977, s. 484-486; J. D. Nogalski, Obadiah 7: Textual Corruption or Politically Charged Metaphor? Zeitschrift für die alttestamentliche Wissenschaft 110/1998, s. 67-71.

113 B d'A XXIII.4-9, s. 102.

114 J. Ziegler (red.), Septuaginta. Vetus Testamentum Graecum, t. XIII: Duodecim prophetae, ad loc. 
w TM) na przeszły w LXX, ukazujący, że dana czynność się już dokonała. Zmiana ta jest obecna we wszystkich ważnych rękopisach LXX ${ }^{115}$ jest więc, jak się wydaje, zmianą celową, interpretacyjną tłumacza LXXAbd. Być może chodziło o to, że kara na Edomitów (Idumeę) już spadła. Zmiana miałaby zatem charakter harmonizujący.

3. Wyrażenie hebrajskie הִּשְׁיאוּ (,zdradzą cię"), tak przetłuma-

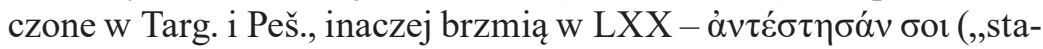
nęli przeciw tobie") i Vul. - inluserunt tibi; lekcje te wynikają, jak się wydaje, z niezrozumienia hebrajskiego rdzenia (por. podobne niezrozumienie w w. 3). ${ }^{116}$

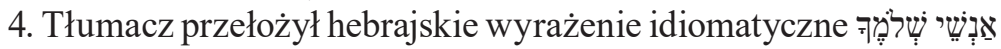

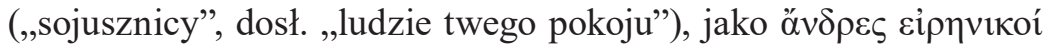
бov (,ludzie twego pokoju”), co jest bardzo dosłownym przekładem ${ }^{117}$ (w grece wręcz niezrozumiałym, co sprawiło, że niektóre mniej ważne kodeksy minuskułowe dodały wyrażenia uzupełniające, by czytelnik grecki wiedział, że chodzi o „,sojuszników”; por. z różnymi zmianami rękopisy: 22, 23, 36, 51, 62, 86, 87, 95, 97, 114, 130, 147, $\left.185,238,240 ; 310^{118}\right)$. Co ciekawe inne wyrażenie idiomatyczne tego

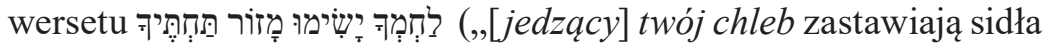
pod tobą”), także oznaczające ,sojuszników”, w LXX zostało w ogóle pominięte (jako niezrozumiałe) - umieszczą je jedynie Aquila i Teodocjon, oddający tekst hebrajski jeszcze bardziej dosłownie niż LXX (odcinając się od tradycji LXX). ${ }^{119}$ Niektórzy zastanawiają się, czy to wyrażenie może być pozostałością interpretacji dwóch poprzednich słów w świetle idiomu לִֶֶֶ (,,jedzący chleb”) użytego w Ps 41,10 (numeracja hebrajska). ${ }^{120}$

115 Drobne zmiany por. J. Ziegler (red.), Septuaginta. Vetus Testamentum Graecum, t. XIII: Duodecim prophetae, ad loc.; oraz Holmes-Parsons, ad loc.

116 BHQ, s. 58 oraz s. 89*.

117 Por. B d'A XXIII.4-9, s. 102.

118 Za Holmes-Parsons, ad loc.

119 Por. B d'A XXIII.4-9, s. 103; BHQ, s. 58 oraz s. 89*.

${ }^{120}$ Por. BHQ, s. 89*. Inne propozycje wyjaśnienia tego trudnego do zrozumienia hebrajskiego wyrażenia zob. G. I. Davies, A New Solution to a Crux in Obadiah 7 , s. 484-486. 
5. W Kodeksach B i S oraz niektórych minuskułach hebrajska

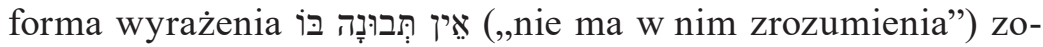

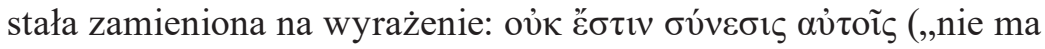
w nich zrozumienia"). W takiej formie cytują ją niektórzy Ojcowie Kościoła $^{121}$. Wiele rękopisów greckich ma to wyrażenie w innym

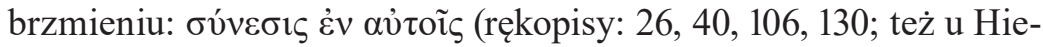

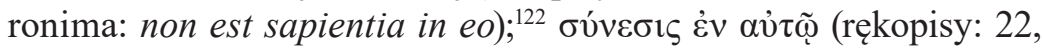
23, 36, 42, 49, 51, 62, 68, 87, 91, 95, 97, 147, 153, 185, 198, 228, 233, 238, 310, 311). ${ }^{123}$ Ta ostatnia jako zawarta w większości rękopisów została przyjęta przez J. Zieglera w wydaniu krytycznym, ta wersja (w liczbie pojedynczej) może nawiązywać do Ezawa z w. 6 i wydaje się bardziej zrozumiała w całym kontekście. Bardzo trudno rozstrzygnąć, która lekcja była pierwotną wersją LXX (czy mniej zrozumiała i bardziej oryginalna zaakceptowana przez A. Rahlfsa? Czy bardziej ujednolicona i zrozumiała w kontekście - co może być późniejszą interwencją korektorską - zaakceptowana przez J. Zieglera).

\section{Werset 8}

Pewną trudność sprawia tłumaczom początkowa partykuła הִ הלוֹא (wyrażająca negację: „czyż nie”, ale i aklamację). LXX w ogóle ją pominęła, podobnie jak Peš., co zresztą jest zabiegiem częstym w obu wersjach (greckiej i syryjskiej), ${ }^{124}$ partykuła obecna jest natomiast w Targumach i Vulg. oraz w rękopisie hebrajskim z Wadi Muraba'at. ${ }^{125}$ W LXX hebrajskie pytanie retoryczne zamienione zostało po prostu na zdanie twierdzące (i to w czasie przyszłym, co zmienia narrację przeszłą z w. 7 i powoduje, że tu, w w. 8 tekstu greckiego, może zacząć się nowa jednostka wypowiedzi proroka). Werset ten w LXX

\footnotetext{
121 B d'A XXIII.4-9, s. 103.

122 Holmes-Parsons, ad loc.

123 Tamże.

${ }^{124}$ Por. BHQ, s. 89*; por. A. Gelston, The Peshitta of the Twelve Prophets, Clarendon Press, Oxford 1987, s. 137.

125 Por. BHQ, s. 58.
} 


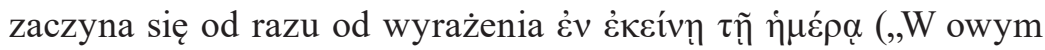
dniu"; tak w rękopisach: 22, 23, 26, 36, 51, 62, 86, 85, 106, 130, 147, 185, $198,233,238,311,{ }^{126}$ za względu na te rękopisy do tekstu przyjmują go wydania Zieglera i Rahlfsa), które w niektórych ważnych rękopisach

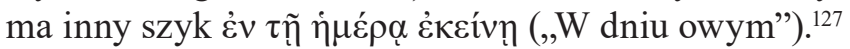

\section{Wersety 9-10}

1. Wyrażenie hebrajskie וְ (,i będą porażeni”), obecne w tej wersji w rękopisach qumrańskich (4Q12 $)$ i odnalezionych w Wadi Murabba'at, jest także obecne w Targ., Vul., oraz wersji Symmacha, zaś zmienia go Peš. ${ }^{128}$ Jego wolne tłumaczenie znajdujemy w LXX:

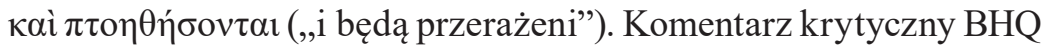
zaznacza, że rdzeń hebrajski חתת może oznaczać zarówno ,porażenie [np. informacją]", jak i ,przerażenie”, ${ }^{129}$ zmiana LXX jest więc wyborem dokonanym przez tłumacza i obecnym we wszystkich najważniejszych rękopisach greckiej wersji Księgi Abdiasza.

2. Podobnie jak powyżej jest z terminem גִּבְּרִ (,twoi wojownicy"), który obecny we wszystkich wersjach starożytnych (także w LXX), zmieniony jest jedynie w Peš., która interpretuje ów teks dostosowując go do kontekstu. ${ }^{130}$

3. Hebrajska nazwa תֵָּּ użyta tu w formie wołacza (,Temanie”),

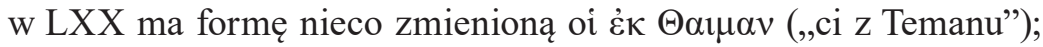
zmiana ma charakter egzegetyczny. ${ }^{131}$ Ciekawe, że inne wersje starożytne także nazwę tę interpretują, a nie tłumaczą: Targ. nawiązuje do „Południa” (podobny zabieg zastosowano w innych częściach Dwunastu Proroków: Am 1,12 oraz Hab 3,3). ${ }^{132}$ Niektóre rękopisy

126 Holmes-Parsons, ad loc.

127 Por. J. Ziegler (red.), Septuaginta. Vetus Testamentum Graecum. t. XIII: Duodecim prophetae, ad loc.

128 BHQ, s. 58.

129 Tamże, s. 89*.

130 Tamże.

131 Tamże, s. 58.

132 Tamże, s. 89*-90*. 
greckie $\left(86,764,198^{133}\right)$ dostosowują tekst grecki do hebrajskiego, jednak zmiana ta ma charakter wtórny. ${ }^{134}$

4. W LXX ostatnie wyrażenie z w. 9 (które w TH brzmiało „,z powodu rzezi”, „od rzezi”), przeniesione zostało do w. 10, two-

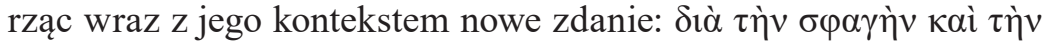

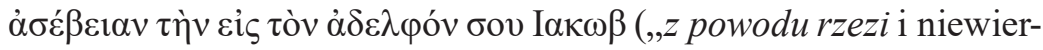
ności [!] wobec brata twego Jakuba"). Interesujące jest dodanie w w.

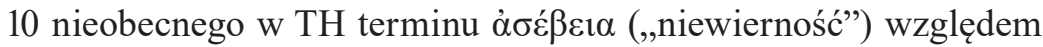
brata (Jakuba). LXX dokonała harmonizacji tekstu, podkreślając ponownie, że prawdziwą przyczyną oskarżenia przeciw Edomitom (Idumei) jest brak wierności względem brata. ${ }^{135}$ Mówiąc krótko, LXX uwypukla obecną w TM teologię, ukazując winę sąsiada, który nie pomógł Izraelitom $\mathrm{w}$ ich potrzebie. ${ }^{136} \mathrm{~W}$ dalszej części księgi padnie to wyraźnie, ale tłumacz już tu dokonał harmonizacji, dodając prawdziwą przyczynę mowy przeciw Edomowi (Idumei). Dalsze wersety tworzące całość z w. 10 uzupełnią tę informację, opisując dokładniej na czym polegała owa zdrada Edomu (Idumei).

\section{Werset 11}

Werset zawiera pierwsze z najważniejszych oskarżeń względem Edomu (Idumei), oskarżenie brata, który stał z boku, a przez bierność stał się winny, tak samo jak atakujący Babilończycy (to, co LXX zaczęła wyjaśniać już w w. 10).

1. Pierwsza zmiana w tym wersecie w LXX względem TH pojawia się już początkowym wyrażeniu (ִִּ (,w dniu”), które LXX zmienia na $\dot{\alpha} \varphi$ ' niejszych historii pomiędzy Izraelem a Edomem (choć te także nie

133 Por. J. Ziegler (red.), Septuaginta. Vetus Testamentum Graecum. t. XIII: Duodecim prophetae, ad loc.

134 BHQ, s. 90*.

135 Harmonizacja była inicjatywą tłumacza LXX; por. BHQ, s. 90*; oraz H. Schmoll, H. Utzschneider, Abdiu. Obadja, w: SepDeutsch, t. II: Psalme bis Daniel, s. 2390.

136 Por. B d'A XXIII.4-9, s. 104. 
należały do wzorcowych), ale zaczyna się „od dnia” w którym brat stanął w opozycji do brata. Zmiana ma charakter interpretacyjny, wyjaśniający, a może jednocześnie być pomyłką w odczytaniu tekstu

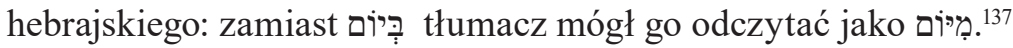

2. Ważna zmiana z zakresu krytyki tekstualnej pojawia się w sty-

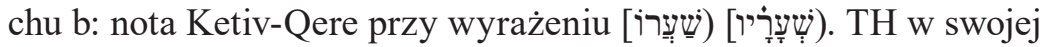
pierwotnej wersji mówi o ,jego bramie" (w liczbie pojedynczej; tak ma też wersja z Wadi Muraba'at, być może w jako dostosowanie do w. 13); nota Masoretów zaznacza, że chodzi o liczbę mnogą: ,jego bramy". Zmiana ma charakter objaśniający - oczywiste jest, że nie jedną bramą wchodzono do miasta podczas oblężenia, ale „bramami jego". W liczbie mnogiej mają to wyrażenie wszystkie wersje staro-

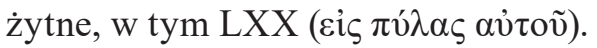

\section{Werset 12}

Werset podkreśla kolejny aspekt winy Edomitów (Idumei). LXXAbd ukazuje, że Edomici (Idumejczycy?) nie tylko pozostawali bierni wobec przemocy, która dotknęła Izraelitów, ale naśmiewali się z nieszczęścia brata. Wina Edomu jest większa - jest nią nie tylko obojętność, ale także satysfakcja, że sąsiadowi dzieje się źle. Jedyną zmianą w LXX (we wszystkich najważniejszych rękopisach) jest ta związana z błędnym odczytaniem rdzenia נָכָּר rdzenia (w wyrażeniu

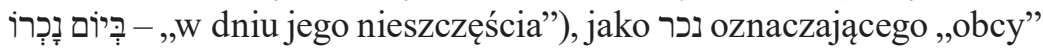
(tym bardziej że rdzeń ten występuje częściej). ${ }^{138} \mathrm{~W}$ taki sam sposób odczytała go Vul. ${ }^{139} \mathrm{~W}$ oby przypadkach nawiązuje to do sytuacji z VI w. przed Chr, gdy owi „obcy” zaatakowali Izraelitów.

\section{Werset 13}

Jeden z bardziej przepracowanych wersetów w całej LXXAbd.

137 BHQ, s. 90*.

138 Tamże.

139 Por. tami̇e, s. 58. 
1. Podobnie, jak w w. 11 (zob. omówienie), w LXX termin w liczbie pojedynczej שֵׁِ (,brama”), zamieniony został na liczbę mnogą $\pi v ́ \lambda \alpha \varsigma$ („bramy”). Taką zmianę względem TH ma również Targ. ${ }^{140}$

2. Tłumacz błędnie odczytał także wyrażenie (עִַ („mój lud”) jako liczbę mnogą (hebr. עַפְִ ), dlatego taki jego przekład: $\lambda \alpha \tilde{\omega} v$. Niektóre rękopisy $\operatorname{LXX}\left(26,49,198,233,534,544^{141}\right)$ poprawiają ten tekst na liczbę pojedynczą, dostosowując go do hebrajskiego oryginału (jest to jednak korekta wtórna). ${ }^{142}$

3. Pozostałe zmiany w LXX względem TH mają charakter interpretacyjny. Trzykrotnie użyty tu termin hebrajski: אֵידָם (,ich klęska"), אידו (, אידו (,jego klęska") orazo klęska"), zostały w LXX

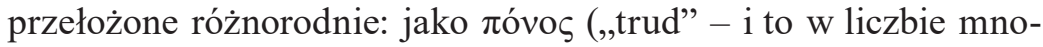
giej), ő $\lambda \varepsilon \theta \rho \circ \varsigma$ (,,zniszczenie”) oraz $\alpha \dot{\pi} \omega \dot{\lambda} \varepsilon 1 \alpha$ (,,ruina”, ,zniszczenie”, „unicestwienie”). ${ }^{143}$ Taka wersja rozróżniająca słowa jest dziełem tłumacza LXX (inne wersje - Targ. i Peš. - oddają trzy hebrajskie słowa tym samym terminem, pow tórzonym trzykrotnie, zachowując charakter tekstu hebrajskiego). ${ }^{144}$ Jedynie Vul. zmienia hebrajski termin, jednak tylko w jednym przypadku (kolejno tłumaczy wyrażenia jako: ruinae eorum, vastitatis illius oraz vastitatis illius). ${ }^{145} \mathrm{Zmiana}$ ta ma na celu dostosowanie przekładu, by całe zdanie lepiej brzmiało po grecku (by nie powtarzać trzy razu tego samego słowa). Zgadza się czas w obu wersjach (hebrajskiej i greckiej), ale cały tekst jest dostosowany do języka, na który jest tłumaczony.

4. Podobny interpretacyjny charakter ma ostatnia zmiana tego

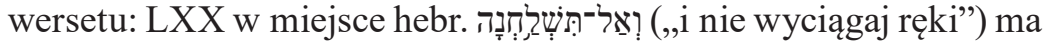
$\mu \eta \delta \varepsilon \dot{\varepsilon} \sigma v v \varepsilon \pi \imath \theta \tilde{n}$ („,nie dołączaj się do ataku”; dosł. „nie współatakuj”). ${ }^{146}$

140 Tamże.

${ }^{141}$ J. Ziegler (red.), Septuaginta. Vetus Testamentum Graecum, t. XIII: Duodecim prophetae, ad loc.

${ }^{142}$ H. S c h m o 11, H. U t z s c h n e i d e r, Abdiu. Obadja, w: SepDeutsch, t. II: Psalme bis Daniel, s. 2390-2391; B d'A XXIII.4-9, s. 106-107.

143 Por. BHQ, s. 90*.

144 Tamże.

145 Tamże, s. 58.

${ }^{146}$ Na temat tej zmiany zob. tamże, s. 91*. 
Choć wyrażenie to sprawiało sporo kłopotów (inaczej brzmi także w Targ. i Peš.), ${ }^{147}$ wydaje się, że przekład LXX harmonizuje tekst wykazując winę Edomu (Idumei) - tu konkretnie w tym, co dotyczy „współatakowania”. Tu tłumacz nie przełożył niewolniczo idiomu hebrajskiego. Cały werset określa to, co robił Edom, a nie powinien, w czasach trudnych da Izraela.

\section{Werset 14}

Werset stanowi kontynuacją wątków rozpoczętych w wersetach poprzedzających. Wylicza kolejne ,grzechy” Edomu (Idumei) względem Izraelitów. Jedyna zmiana to liczba mnoga, która (nieobecna w TH) pojawia się w LXX, w wyrażeniu $\tau \grave{\alpha} \varsigma \delta ı \varepsilon \kappa \beta o \lambda \grave{\alpha} \varsigma$ (,na przejściach”), z dodatkiem $\alpha$ $\tau \tilde{\omega} v$ (,ich”). Wydaje się, że to dość swobodne tłumaczenie ${ }^{148}$ może mieć wartość eksplikacyjną: tłumacz jednoznacznie określa, co robili Edomici - nie stali na jakimś przejściu, ale na „ich (!), czyli Izraelitów, przejściach” (liczbę mnogą w tym miejscu ma też Vul. ${ }^{149}$ ) - atakując ocalałych z ataku Babilończyków Izraelitów. Obraz Edomitów (Idumei) jest tu jeszcze mocniejszy i nie pozostawia wątpliwości co do ich winy. ${ }^{150}$ Podobny cel ma dodatek $\mathrm{z}$ drugiego stychu, zawierający także nieobecne w hebrajskim tekście wyrażenie $\dot{\varepsilon} \xi \alpha u ̛ \tau \tilde{\omega} v$ (,spośród ich”).

\section{Wersety 15-16}

Centralne wersety całej księgi. Po wcześniej określonej winie, przychodzi moment zapowiedzi kary - jako konsekwencji tamtych działań (lub zaniechania). O ile w. 15 nie zawiera poważnych zmian w tekście LXX, ${ }^{151}$ o tyle w. 16 ma kilka interesujących wariantów.

\footnotetext{
147 Tamże, s. 59.

148 Tamże, s. 91*.

149 Tamże, s. 59.

150 Por. objaśnienie tego wersetu w B d'A XXIII.4-9, s. 107.

151 Por. jego omówienie w tamże, s. 107-108.
} 
1. Liczba pojedyncza czasownika ह̌ $\pi 1 \varepsilon \varsigma$ (,,piłeś”) w stychu pierwszym (TH miał tu liczbę mnogą), nawiązuje gramatycznie do w. 15 (gdzie również mowa była o 2 . osobie liczby pojedynczej) i jest harmonizacją gramatyczną tekstu. ${ }^{152}$

2. Dookreślenie „święta ma góra” ma z kolei nie pozostawiać wątpliwości, o którą górę chodzi - o górę Syjon, górę Bożą, a nie jakąś inną świętą górę, znaną w świecie tłumacza LXX (zmiana ma charakter interpretacyjny i jest obecna we wszystkich najważniejszych świadkach tekstu greckiego (poza rękopisem $22^{153}$ ).

3. Najciekawsze zmiana dotyczy nieobecnego w TH, a obecnego we wszystkich rękopisach LXX terminu oĩvos (,wino"). ${ }^{154}$ Jest to oryginalna lekcja LXX, w miejsce obecnej we wszystkich wersjach

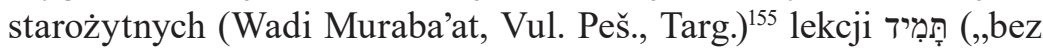
końca"). Być może tłumacz odczytał błędnie hebrajski rdzeń jako: 156

4. Trudny do zrozumienia hebrajski hapax legomenon וְרְעו (,,i połkną”), oddany tak w Targ. u Vul., obecny także w rękopisie z Wadi Murabaa’t, w LXX został przełożony na dwa sposoby - w zależności

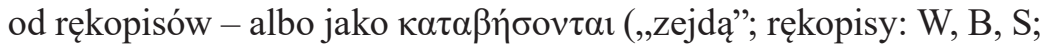
w takiej formie przyjęty przez A. Rahlfsa ${ }^{157}$ i J. Zieglera ${ }^{158}$ ), albo jako

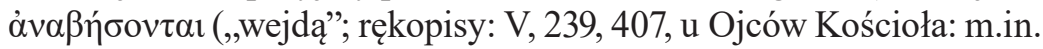
Cyryla Aleksandryjskiego, Teodoreta z Cyru, Teodora z Mopsuestii; ${ }^{159}$

152 Por. tamże, s. 107-108; oraz H. Schmoll, H. Utzschneider, Abdiu. Obadja, w: SepDeutsch, t. II: Psalme bis Daniel, s. 2391.

${ }^{153}$ Holmes-Parsons, ad loc.; J. Ziegler (red.), Septuaginta. Vetus Testamentum Graecum, t. XIII: Duodecim prophetae, ad loc.

${ }^{154}$ Por. B d'A XXIII.4-9, s. 108; oraz H. Schmoll, H. Utzschneider, Abdiu. Obadja, w: SepDeutsch, t. II: Psalmen bis Daniel, s. 2391.

155 BHQ, s. 59.

156 Tamże, s. 91*.

157 A. Rahlfs, R. Hanhart (red.), Septuaginta. Id est Vetus Testamentum graece, ad loc.

158 J. Ziegler (red.), Septuaginta. Vetus Testamentum Graecum, t. XIII: Duodecim prophetae, ad loc.

159 Por. tamże, ad loc. 
oraz w rękopisach: 22, 36, 51, 62, 95, 114, 147, 185, 238, 240 ${ }^{160}$ ). Takie odczytanie mogło wynikać w trudności ze zrozumieniem hebraj-

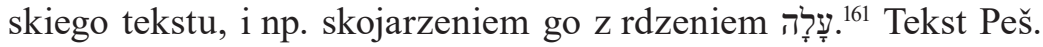
przyjmuje znaczenie tego hebrajskiego terminu jako „siorbanie” i tłumaczy to wyrażenie podwójnie (jako siorbanie i połykanie) może jako alternatywne odczytanie tego tekstu. ${ }^{162}$

\section{Wersety 17-18}

Rozpoczynają nową, ostatnią, część wypowiedzi proroka, w któ-

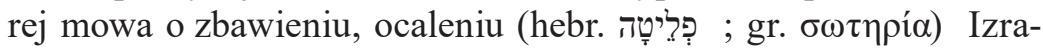

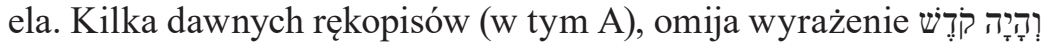
(,i będzie święta”) - odniesione w TH do góry Syjon z w. 17. ${ }^{163}$ Być może rękopisy te pominęły to wyrażenie w wyniku błędu homoioarchton (albo w wyniku tego samego błędu pojawiło się ono w TM, choć obecne jest ono we wszystkich wersjach: Targ. Peš, Vul., oraz W rękopisie z Wadi Muraba'at). ${ }^{164} \mathrm{~W}$ w. 18 trudne wyrażenie שָרִיד

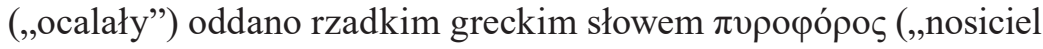
ognia”) - w przenośnym znaczeniu „ocalały”, tak używany w literaturze klasycznej: u Herodota, i u Filona. ${ }^{165}$

\section{Wersety 19-20}

Bardzo ciekawe zmiany w LXX pojawiają się w ww. 19-20, które podają różne nazwy geograficzne (które w LXX często ulegają zmianom, także w zbiorze Dwunastu Proroków). ${ }^{166} \mathrm{O}$ ile nazwy geogra-

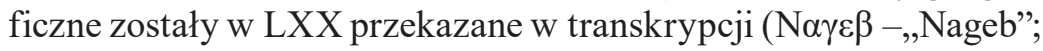

\footnotetext{
${ }^{160}$ Holmes-Parsons, ad loc.

161 Por, BHQ, s. 91*; oraz B d'A XXIII.4-9, s. 108.

162 BHQ, s. 91*.

163 Por. tamże, s. 59; B d'A XXIII.4-9, s. 109; oraz H. Schmoll, H. Utzschneider, Abdiu. Obadja, w: SepDeutsch, t. II: Psalmen bis Daniel, s. 2391.

164 Por. BHQ, s. 59 , 91*.

165 Por. tamże, s. 91*.

166 Na ten temat zob. B d'A XXIII.4-9, s. 89, 110-112.
} 
Szefela, jako $\Sigma \varepsilon \varphi \eta \lambda \alpha$,,Sefela”), o tyle nazwy ludów zostały zmienione:

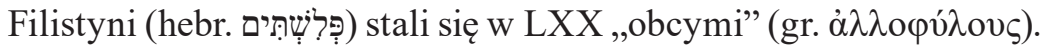
Ta konkretna zmiana może mieć cel uogólniający przesłanie - o ile kiedyś dla Izraelitów wrogami byli Filistyni, o tyle w czasach autora wrogami są wszyscy „obcy” - i w ten sposób orędzie greckiej księgi zostało poddane alegoryzacji i uniwesalizacji: dotyczyć ma każdego ludu i narodu „obcego”. Wszystkie te ziemie wyliczone w ww. 19-20 Pan da swojemu ludowi.

Ponieważ wersety te zawierały informacje geograficzne trudne do interpretacji, czasem - tak robili to Ojcowie Kościoła, np. Hezychiusz ukazywano ich jako symbole zła, grzechu (czyli w chrześcijańskich interpretacjach dokonano jeszcze dalej idącej ich alegoryzacji). ${ }^{167} \mathrm{~W} .20$, bardzo trudny, doczekał się zresztą wielu interpretacji współczesnych tekstu hebrajskiego, ale i jego starożytnych wersji: LXX i Vulg. ${ }^{168}$

\section{Werset 21}

Najważniejszą zmianą ostatniego wersetu księgi jest ta odnosząca się do hebrajskiego terminu מוֹשִׁעי (,wyzwoliciele”), który w LXX

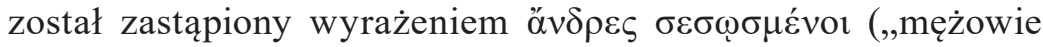
ocaleni”) ${ }^{169}$ Taką lekcję zawierają ważne rękopisy LXX (A, Q, W), ${ }^{170}$ jak również Peš., oraz wersje Akwili i Teodocjona, zaś wersję TM dzielą także Vul. i Targ. ${ }^{171}$ Zmiana ma charakter dostosowujący w. 21

167 Por. B d'A XXIII.4-9, s. 111.

168 Por. J. Gray, The Diaspora of Israel in Judah in Obadiah v. 20, Zeitschrift für die alttestamentliche Wissenschaft 65/1953, s. 53-59; E. Lipiński, Obadiah 20, Vetus Testamentum 23/1973, s. 368-370; D. Weissert, Obadiah 20: Septuagint and Vulgate, Textus: Studies of the Hebrew University Bible Project 24/2009, s. 85-106. Por. także: B d'A XXIII.4-9, s. 111-112; H. Schmoll, H. Utzschneider, Abdiu. Obadja, w: SepDeutsch, t. II: Psalme bis Daniel, s. 2392-2393.

169 Por. BHQ, s. 60.

170 Por. A. Rahlfs, R. Hanhart (red.), Septuaginta. Id est Vetus Testamentum graece, ad loc.; J. Ziegler (red.), Septuaginta. Vetus Testamentum Graecum, t. XIII: Duodecim prophetae, ad loc.

171 Por. BHQ, s. 60. 
do w. 17, jest być może wynikiem błędnego odczytania rdzenia hebrajskiego. ${ }^{172}$ I zdaje się być pierwotna, choć niektóre ważne rękopisy

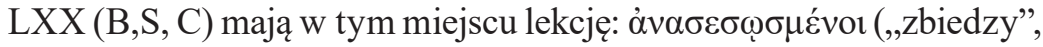
„uciekinierzy”), być może nawiązującą do ocalonych z wspomnianych poprzednio wersetów (tych zdradzonych przez wroga), którzy w dniu kary będą nie tylko ocaleni, ale to oni staną się autorami nowego królestwa Bożego, które nastanie. I to oni sądzić będą także Ezawa, swego zdrajcę. ${ }^{173}$

\section{Charakter przekładu LXXAbd}

Księga Abdiasza w Biblii Hebrajskiej jest utworem poetyckim, jedynie ostatnie wersety (19-21) są pisane prozą w BH (widać to nawet w wydaniach krytycznych; por. BHQ). Ponieważ język i przesłanie księgi nie były łatwe, tłumacze starożytni musieli zmierzyć się z rozmaitymi trudnościami w ich przekładzie. Wersja grecka Księgi Abdiasza, zawarta w LXX, ma kilka charakterystycznych cech, które z jednej strony są typowe dla wszystkich ksiąg zbioru Dwunastu Proroków (gdzie charakter przekładu można określić jako ,raz bardziej, raz mniej wierny"174), a z drugiej ukazują samą księgę w nieco innym, bardziej uniwersalnym świetle. Cechami tego przekładu są: wierność, bogactwo słownictwa, aktualizacja i harmonizacja.

1. Wierność: czasem więc niewolnicza (np. w w. 4; w w. 7, gdzie tłumacz wiernie co do słowa przekłada wyrażenie idiomatyczne hebrajskie, które w języku greckim brzmi karykaturalnie; w w. 15, gdzie tłumacz zachował nawet składnię hebrajską, pisząc po grecku, nie używając czasu teraźniejszego); ale nie tylko niewolnicza (inne wyrażenia idiomatyczne z ww. 14 i 15 przełożone są co do sensu; a inne-jak z w. 1,7 - pominięte przez tłumacza). Naturalnie, czasem

172 Por. tamże, s. 92*.

173 Na temat tego wersetu w LXX, zob. B d'A XXIII.4-9, s. 112-113.

174 Por. G. E. Howard, The Twelve Prophets. To the Reader, w: NETS, s. 777 (zob. także krótkie omówienie wszystkich cech charakterystycznych zbioru: tamże, s. 777-780). 
tłumacze nie uniknęli błędnego odczytania rdzeni, zwłaszcza tam, gdzie słownictwo było trudne (dwukrotnie w w. 16, raz przy przekładzie hebrajskiego terminu hapax legomenon) i innych błędów (jak możliwy homoioarchton w w. 17).

2. Bogactwo słownictwa; widać, że tłumacz (tłumacze) był człowiekiem wykształconym; używa oryginalnego słownictwa znanego z literatury klasycznej (np.: w. 1: $\pi \epsilon \rho \iota \chi \chi \eta,-$, wiadomość pisana”; w. 4: $\mu \epsilon \tau \epsilon \omega \rho i \zeta o \mu \alpha \iota-$, ,szybować, jak orzeł”, ale i „,martwić się; w. 5:

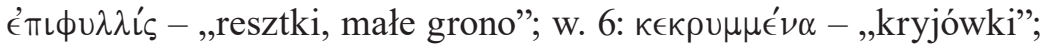
w. 12: $\mu \epsilon \gamma \alpha \lambda \circ \rho \rho \eta \mu о \nu \epsilon ́ \omega-$,wielomówstwo”, ale też „,megalomania”,

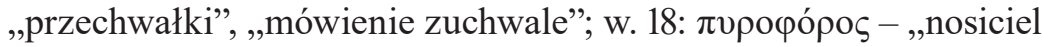
ognia”, „ocalały” i in.), jego przekład był owocem myśli żydowskiej, ale wyrażonej w kategoriach hellenistycznych.

3. Aktualizacja i harmonizacja tekstu: czasami tylko na poziomie gramatycznym czy terminologicznym (np. w 1,1, gdzie dokonuje ujednolicenia podmiotu; czy podobne gramatyczne w ww. 3.4.6.7.11; czy w w.13, gdzie tłumacz jedno słowo hebrajskie powtarzane w zdaniu trzykrotnie przełożył trzema różnymi słowami, żeby się nie powtarzać; czy w w. 16, gdzie liczba pojedyncza czasownika w stychu pierwszym nawiązuje gramatycznie do w. 15; podobnie, jak wcześniej dostosował - przez zmianę czasu - w. 8 do w. 7), a czasem owe harmonizacje i aktualizacje dostosowują tekst Księgi do czasów i potrzeb wspólnoty, dla której powstawało tłumaczenie.

Te zmiany świadome i interpretacyjne są najciekawsze, a w przypadku zmian wyliczonych poniżej nie ma wątpliwości, że są one dziełem tłumacza LXX.

Pierwszą z najważniejszych zmian jest zmiana nazwy głównego

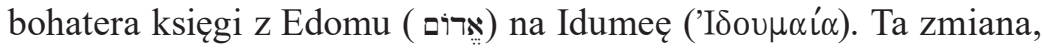
obecna jest w ww. 1 i 8, dotyczy treści całej księgi i jest elementem harmonizacji i aktualizacji tekstu. ${ }^{175}$ Występuje ona w LXX także w pozostałych Księgach Dwunastu Proroków (por. Am 1,6.9.11; 2,1;

175 Por. B d'A XXIII.4-9, s. 89; oraz H. Schmoll, H. Utzschneider, Abdiu. Obadja, w: SepDeutsch, t. II: Psalme bis Daniel, s. 2389. 
J1 4,19; Ml 1,4) i w innych miejscach w LXX. ${ }^{176}$ I choć zdarza się, że termin Edom ( ארוֹם) przekładany jest w LXX jako E $\delta \omega \mu$ - zarówno imię własne, jak i nazwa krainy i jej mieszkańców, ${ }^{177}$ to nie zdarza się to w Księgach Dwunastu Proroków. Wydaje się to więc zasada przekładu zastosowana przez tłumacza całego tego zbioru. I jest zarazem argumentem za tym, że przekład wszystkich Dwunastu Proroków wyszedł spod jednej ręki. Zmiana ta miała na celu uogólnienie przesłania ksiąg, co w przypadku LXXAbd ma szczególne znaczenie: Edomici w czasach powstawania przekładu Księgi Abdiasza już nie istnieli, istniała jednak Idumea i jej mieszkańcy, którzy wraz ze zmianą stali się symbolem wroga w każdym czasie.

Bardzo ciekawa i podobna w charakterze zmiana w LXXAbd pojawia się w ww. 19-20, które podają różne nazwy geograficzne, które w tym konkretnym kontekście nadają znowu wartość uniwersalną przesłaniu księgi. Chodzi zwłaszcza o zmianę terminu Filistyni (hebr.

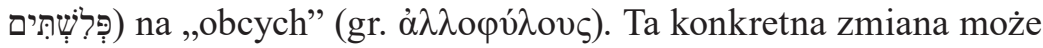
mieć cel uogólniający przesłanie - o ile kiedyś dla Izraelitów wrogami byli Filistyni (jak i Edomici), o tyle w czasach autora przekładu wrogami są wszyscy „obcy” - i tak orędzie księgi zostaje poddane

176 Np. Rdz 36,16 (pozostałe przypadki w Rdz przekłada termin Edwm); Joz 15,1; 2Sm 8,12.13.14 (dwukrotnie) - mowa o Edomie lub Edomitach; 1Krl 11,1 (mowa o Edomitkach - Idumejkach); 11,14 (mowa o Edomicie - Idumejczyku); 11,15.16 (dwukrotnie) (Edom - Idumea); 2Krl 14,10; 1Krn 18,11.12; 2Krn 8,17; 25,14.19; Ps 59,10.11 (według numeracji hebrajskiej 60,10.11); 82,7 (według numeracji hebrajskiej 83,7); 107,10.11 (według numeracji hebrajskiej 109,10.11); Am 1,6.9.11; 2,1; J1 4,19; M1 1,4; Iz 11,14; 21,11; 34,5.6; Jr 30,1.11.14.16 (według numeracji hebrajskiej 49,7.17.20.22); 32,21 (według numeracji hebrajskiej 25,21); 34,3 (według numeracji hebrajskiej 27,3), 47,11 (według numeracji hebrajskiej 40,11); Lm 4,21; Ez 25,12.13.14 (dwukrotnie); Ez 35,15; 36,5. Ponadto termin ten występuje też w księgach deuterokanonicznych (1Mch 4,15. 29. 61; 5,3; 6,31; 2Mch 12,32; dodatek LXX do Hioba: LXXHi 42,17), i raz w NT (Mk 3,8).

177 Por. Rdz 25,30; 32,4; 36,1.8.9.17.19.21.30.31.32.43; Wj 15,15; Lb 20,14.18.20.21.23; 21,4; 24,18; 33,37; 34,3; Joz 15,21.44; Sdz 5,4; 11,17.18; $1 \mathrm{Sm}$ 14,47; $1 \mathrm{Krl}$ 9,26; 11,15.25; $2 \mathrm{Krl} 3,8.9 .12 .20 .26$; 8,20.21.22; 14,7; 1Krn 1,51.54; 2Krn 21,8.9.10; Ps 136,7; Iz 63,1; Jr 9,25; Lm 4,22; Dn 11,41); termin ten występuje też w księgach deuterokanonicznych i dodatkach właściwych tylko LXX: Ody Salomona 1,15; LXXHi 42,17. 
alegoryzacji i uniwersalizacji: dotyczyć może każdego ludu i narodu „obcego". Ten sam termin pojawia się zresztą w w. 12, otwierając tekst grecki (a także Vul.) na bardziej ogólną, uniwersalną interpretację.

Podobnemu celowi służą też inne lekcje LXX: zmiana czasów i trybów (z przyszłego na dokonany, gdy zarazem Ezaw z przedmiotu staje się podmiotem; w w. 6; lub z przyszłej na przypuszczającą, w w. 5); liczby mnogiej i pojedynczej na odwrotną (np. w w. 14) Wszystkie one nie pozostawiają wątpliwości co do winy oskarżanych, a obraz wrogów w LXXAbd - jest w konsekwencji jeszcze mocniejszy niż w TH. Jasno tę winę określają ww. 9-10, przenosząc część w. 9 do w. 10, ukazując, że kara na wroga spadnie z powodu jego winy: „,z powodu rzezi [przeniesione z w. 9] i niewierności [!] wobec brata twego Jakuba". Prawdziwą przyczyną oskarżenia przeciw Edomitom (Idumejczykom?) - jest oskarżenie sąsiada (brata), który nie pomógł. W dalszej części księgi padnie to jeszcze wyraźniej: kolejne wersety ukażą, czego dokładnie dokonał (lub raczej nie dokonał) Edom (Idumea). LXX podkreśla obecną w TM teologię, ukazując winę sąsiada (brata), który nie pomógł Izraelitom w ich potrzebie, a nawet nie tylko pozostawał bierny wobec przemocy, która dotknęła Izraelitów, ale naśmiewał się z niej. Wina Edomu (Idumei) jest większa - jest nią nie tylko obojętność, ale także satysfakcja, że sąsiadowi dzieje się źle. Taką postawę wielokrotnie prezentował zresztą także sam Izrael (por. Księga Nahuma), choć tu ją wyraźnie potępia u innych. ${ }^{178}$

W tym kontekście ważna jest także zmiana zawarta w w. 21, gdzie hebrajski termin ,wyzwoliciele” został zamieniony na „ocalałych” lub (w niektórych rękopisach LXX), na „zbiegów”, „uciekinierów”, co nawiązuje do tych, którzy, uciekając przed Babilończykami, wpadli $\mathrm{w}$ ręce wroga. To oni, zgodnie z ostatnim akcentem księgi, staną się autorami nowego królestwa Bożego, które nastanie. I tymi, którzy osądzą swego zdrajcę (kimkolwiek by nie był).

Zmiany w LXXAbd podkreślają zarazem rolę Boga Jedynego takiemu celowi służą podkreślone w w. 16 posesywny zaimek „moja”

${ }^{178}$ Ciekawe byłoby w tym kontekście mieć pisma prezentujące sytuację, która stała się inspiracją dla Abd, w ujęciu Edomitów. 
(w wyrażeniu ,święta ma góra” - oczywiście Syjon), a także podkreślenie Bożego królowania w w. 21, kończącym księgę (tekst LXX jasno podkreśla, ze królestwo nawet odtworzone przez synów Izraela będzie należeć do Pana).

$$
* * *
$$

Z interpretacją Księgi Abdiasza (niezależnie od jej wersji starożytnej) największy kłopot mieli komentatorzy chrześcijańscy. Jak pogodzić jej partykularyzm izraelski (zradykalizowany jeszcze w LXX) z uniwersalizmem nauczania Jezusa? Jak zinterpretować fakt, że księga złorzecząca sąsiadowi jest częścią natchnionego słowa Bożego? Z pomocą przyszła wspomniana wcześniej, dokonana już na poziomie przekładu LXX, alegoryzacja tekstu. Ponieważ już na etapie kształtowania Starego Testamentu Edom stał się paradygmatem wszelkiego wrogiego sąsiada, a grecki przekład zawarty w LXX jeszcze ów paradygmat aktualizował do czasów, w których żyli tłumacze księgi i ich odbiorcy, to teolodzy wczesnochrześcijańscy poszli jeszcze o krok dalej: interpretując Księgę Abdiasza i jej wrogów kluczu walki ze złem w ogóle. Czynili to może pod wpływem LXX) zwłaszcza greccy Ojcowie ${ }^{179}$ (którzy poświęcili jej spore komentarze: Teodor z Mopsuestii (350?-428), Cyryl Aleksandryjski (350-444) i Teodoret z Cyru (393-466). Rozwinęli oni interpretacje księgi: od wrogości braci Ezawa i Jakuba do wrogości narodów, Izraelitów i Edomitów, a następnie do pojęcia wrogości między ludźmi i walki ze złem i grzechem. ${ }^{180}$ „Tekst Księgi Abdiasza i jej patrystyczne interpretacje ukazują bardzo interesujący rozwój, jeśli chodzi o rozumienie Edomu. Najpierw Edom jest bratem/ bratnim narodem, który

\footnotetext{
179 Por. V. Salanga, Księga Abdiasza, s. 1022-1023.

${ }^{180}$ Pewne wątki Abd można znaleźć już na kartach Nowego Testamentu; zob. D. Luckensmeyer, Intertextuality between Obadiah and First Thessalonians, w: C. A. Evans, H. D. Zacharias (red.), "What does the Scripture say ?” Studies in the Function of Scripture in Early Judaism and Christianity, t. 2, T \& T Clark, London-New York 2012, s. 98-120.
} 
stał się wrogiem, później, w kontekście kultu i redakcji literackiej typem albo symbolem wszystkich wrogich narodów Judy, wreszcie - u Ojców greckich - uosobionym złem, diabłem". ${ }^{181}$ Podobnie Ojcowie Zachodni - Hieronim i Augustyn - poświęcili Edomowi uwagę, odnosząc pojęcie wroga do wrogów Kościoła i do grzechu a walkę z Edomem ukazując jako obraz walki duchowej człowieka.

Co ciekawe, w ślady pisarzy chrześcijańskich poszli także rabini, którzy również w czasach pobiblijnych zaczęli interpretować Księgę Abdiasza w kluczu alegorycznym, widząc w obrazie Edomu - nie tylko każdego „obcego”, ale bardzo konkretnie identyfikując go np. z Rzymem, ${ }^{182}$ co niewątpliwie miało także wydźwięk polemiczny z chrześcijaństwem.

I tak na niewielka Księga Abdiasza stała się inspiracją i motywem tak ważnej teologii, powtarzanej w różnych okolicznościach historycznych, także obecnie, w kontekstach wyzwoleńczych, feministycznych $\mathrm{i}$ innych, ale temu należałoby poświęcić odrębne studium. ${ }^{183}$

\section{Barbara STRZAEKOWSKA}

181 V. Salanga, Księga Abdiasza, s. 1023.

182 Zob. B d'A XXIII.4-9, s. 98. Na temat interpretacji rabinicznych zbioru Dwunastu Proroków, w tym Abd, zob. The Twelve Prophets = תרי עשר = Trei asar: a new translation with a commentary anthologized from Talmudic, Midrashic and rabbinic sources, t. 1-2, ArtScroll Tanach Series: a traditional commentary on the Books of the Bible, Mesorah Publications, New York 2009-2015; J. Neusner (red.), Habakkuk, Jonah, Nahum and Obadiah in Talmud and Midrash: a source book, Studies in Judaism, University Press of America, Lanham-Toronto-Plymouth 2007.

183 Por. B. A. Anderson, The reception of Obadiah: some historical, ideological, and visual considerations, Proceedings of the Irish Biblical Association 36-37/2013-2014, s. 17-35; S. Almada, Abdias: la injusticia no quedará impune, w: tenże, Voces proféticas en acción: colección de estudios sobre profecía bíblica en clave de liberación, Universidad Católica de Córdoba, Córdoba 2014, s. 123-139; Ph. J. Botha, Social Values in the Book of Obadiah, Old Testament Essays, 16/2003, s. 581-597; B. Glazier -Mc Donald, Obadiah, w: C. A. Newsom (red.), The Women's Bible Commentary, Westminster John Knox Press, Louisville 1992, s. 210-211. 
Słowa-kluczowe: LXXAbd; charakter przekładu LXX; krytyka tekstualna LXX; Księga Dwunastu Proroków w LXX

Keywords: LXX-Oba; the nature of the LXX translation; textual criticism of the LXX; The Book of the Twelve in the LXX

\section{The Book of Obadiah in the Septuagint}

\section{Summary}

The Book of Obadiah, though short (only 21 verses; the shortest book of the Hebrew Bible), is difficult all the same. Its difficulties are manifested on the linguistic and textual level, but above all in what concerns its content, theology and interpretation. The Greek translation of Oba in the LXX is particularly important because it presents a way of understanding of the Book dating back to pre-Christian era, Hellenistic times, which strongly emphasized the theme of threats towards Israel from other nations. In the LXX-Oba the curses against enemies (Edom - Idumea) are radicalized and their guilt highlighted. The article presents the Book of Obadiah in its historical context (both of the Hebrew original and the Greek version), as well as its text, content and character in the Septuagint version. The article compares the text of the LXX-Oba with LXX-Jr 29 and shows how difficult theology of the Book was understood among the Jews of Hellenistic Alexandria. The universalization of the message of the Book translated by the LXX later found continuity in its patristic and rabbinical interpretations.

\section{Bibliografia}

Almada S., Abdías: la injusticia no quedará impune, w: tenże, Voces proféticas en acción: colección de estudios sobre profecía bíblica en clave de liberación, Universidad Católica de Córdoba, Córdoba 2014, s. 123-139.

Anderson B.A., The reception of Obadiah: Some Historical, Ideological, and Visual Considerations, Proceedings of the Irish Biblical Association 36-37/2013-2014, s. 17-35.

Assis E., Structure, redaction and significance in the prophecy of Obadiah, Journal for the Study of the Old Testament 39(2014)2, s. 209-221.

Aussedat M., Le regroupement des livres prophétiques dans la Septante d'après le témoignage des chaînes exégétiques, w: M.K.H. Peters (red.), 
XII Congress of the International Organization for Septuagint and Cognate Studies Leiden 2004, Society of Biblical Literature. Septuagint and Cognate Studies 54, Atlanta, Georgia 2006, s. 169-185.

Bargellini F., Il ruolo canonico di Gioele, Abdia e Giona. Elementi per una lettura unitaria dei XII Profeti Minori, Rivista biblica 55/2007, s. 145-163.

Barthélemy D., Les devanciers d.'Aquila, Vetus Testamentum Supplements 10, Brill, Leiden 1963.

Beck M., Das Dodekapropheton als Anthologie, Zeitschrift für die Alttestamentliche Wissenschaft 118/2006, s. 558-583.

Ben Zvi E., A Historical-Critical Study of the Book of Obadiah, Beiheft zur Zeitschrift für die Alttestamentliche Wissenschaft 242, Walter de Gruyter, New York 1996.

Biddle M.E., Obadiah-Jonah-Micah in Canonical Context: the Nature of Prophetic Literature and Hermeneutics, Interpretation 61/2007, s. 154-166.

La Bible d'Alexandrie. [XXIII], Les Douze Prophètes. 4-9, Joël, Abdiou, Jonas, Naoum, Ambakoum, Sophonie, red. M. Harl, C. Dogniez, L. Brottier [et al.] traduction du texte grec de la Septante, introduction et notes, Éditions du Cerf, Paris 1999.

Bogaert P.-M., L'Organisation des grands recueils prophétiques, w: J. Vermeylen (red.), Le Livre d'Isaïe, Bibliotheca Ephemeridum Theologicarum Lovanieniuum 81, Leuven 1989, s. 147-153 (zwł. s. 148-149).

Botha Ph.J., Social Values in the Book of Obadiah, Old Testament Essays 16/2003, s. 581-597.

Brooke G.J., The Twelve Minor Prophets and the Dead Sea Scrolls, w: A. Lemaire (red.), Congress Volume Leiden 2004, Brill, Leiden 2006, s. 19-44.

Chrostowski W., Babilońskie deportacje mieszkańców Jerozolimy i Judy (597-582 r. przed Chr.), w: tenże, Babilońskie deportacje mieszkańców Jerozolimy i Judy oraz inne studia, Rozprawy i Studia Biblijne 34, Oficyna Wydawnicza „Vocatio”, Warszawa 2009, s. 35-79.

Davies G.I., A New Solution to a Crux in Obadiah 7, Vetus Testamentum, 27/1977, s. 484-486.

Deissler A., Zwölf Propheten II: Obadja, Jona, Micha, Nahum, Habakuk, NEB. AT 8, Echter, Würzburg 1984.

Dicou B., Edom, Israel's Brother and Antagonist: The Role of Edom in Biblical Prophecy and Story, Journal for the Study of the Old Testament Supplement Series (JSOTS) 169, JSOT Press, Sheffield 1994.

Dines J.M., Verbal and Thematic Links between the Books of the Twelve in Greek and Their Relevance to the Differing Manuscript Sequences, w: R. Albertz, J.D. Nogalski, J. Wöhrle, Perspectives on the Formation of the Book of 
the Twelve: Methodological Foundations - Redactional Process - Historical Insights, De Gruyter, Berlin 2012, s. 355-370.

Dines J.M., The Minor Prophets, w: J.K. Aitken (red.) The T\&T Clark Companion to the Septuagint, Bloomsbury T\&T Clark, London i in. 2015, s. 439-440.

Dogniez C., Le Dieu des armées dans le Dodekapropheton, w: B.A. Taylor (red.), IX Congress of the International Organization for Septuagint and Cognate Studies, Cambridge 1995, Society of Biblical Literature Septuagint and Cognate Studies Series 45, Atlanta 1997, s. 19-36.

Dogniez C., Fautes de traduction, ou bonnes traductions? w:, B.A. Taylor (red.), $X$ Congress of the International Organization for Septuagint and Cognate Studies, Oslo 1998, red. B.A. Taylor, Society of Biblical Literature Septuagint and Cognate Studies Series 51, Atlanta 2001, s. 241-261.

Dykehouse J., Biblical evidence from Obadiah and Psalm 137 for an Edomite treaty betrayal of Judah in the sixth century B.C.E. Antiguo Oriente 11/2013, s. $75-128$.

Farisani E.B., The ethnic tensions between the Edomites and the Israelites in Obadiah, Journal for Semitics-Tydskrif vir Semitistiek, 19(2010)2, s. $566-583$.

Gądecki S., Archeologia biblijna, t. 1, Gniezno 1994.

Glazier-McDonald B., Obadiah, w: C.A. Newsom (red.), The Women's Bible Commentary, Westminster John Knox Press, Louisville 1992, s. 210-211.

Glenny W.E., Hosea. A Commentary Based on Hosea in Codex Vaticanus, Leiden-Boston 2013.

Gray J., The Diaspora of Israel in Judah in Obadiah v. 20, Zeitschrift für die alttestamentliche Wissenschaft 65/1953, s. 53-59.

The Greek Minor Prophets Scroll from Nahal Hever (HevXIIgr), Discoveries in the Judean Desert VIII; red. E. Tov, R. Kraft, P.J. Parsons, Clarendon Press, London-Oxford 1990.

Guillaume Ph., A Reconsiderations of Manuscripts Classified as Scrolls of the Twelve Prophets (XII), Journal of Hebrew Scriptures 7/2007, s. 1-12.

Habakkuk, Jonah, Nahum and Obadiah in Talmud and Midrash: A Source Book, red. J. Neusner, Studies in Judaism, University Press of America, Lanham-Toronto-Plymouth 2007.

Hagedorn A.C., Die Anderen im Spiegel: Israels Auseinandersetzung mit den Völkern in den Büchern Nahum, Zefanja, Obadja und Joel, Beihefte zur Zeitschrift für die alttestamentliche Wissenschaft 414, De Gruyter, Berlin-Boston (Mass.) 2011. 
Harrison C.R., The Unity of the Minor Prophets in the LXX: A Reexamination of the Question, Bulletin of the International Organization for Septuagint and Cognate Studies 21/1988, s. 55-72.

Hartberger B., ,An den Wassern von Babylon ...”. Psalm 137 auf dem Hintergrund von Jeremia 51, der biblischen Edom-Traditionen und babylonischer Originalquellen, Bonner biblische Beiträge 63, Frankfurt a.M. - Bonn 1986.

Howard G.E., The Twelve Prophets. To the Reader, w: A. Pietersma, B.G. Wright (red.), A New English Translation of the Septuagint. And the Other Greek Translations Traditionally Included under that Title, New York-Oxford 2007 [NETS], s. 777-781.

Jeppesen K., "The Lord God Has Spoken and Who Will Not Prophesy?" From Osee to Jonas in the Septuagint, w: C. McCarthy, J.F. Healey (red.), Biblical and Near Eastern Essays. Festschrift for K.J. Cathcart, Sheffield Academic Press, Sheffield 2004, s. 105-117.

Jones B., The Formation of the Book of the Twelve: A Study in Text and Canon, Scholars Press, Atlanta 1995.

Joosten J., A Septuagintal Translation Technique in the Minor Prophets. The Elimination of Verbal Repetitions, w: G. Martínez Florentino (red.), Interpreting Translation, Bibliotheca Ephemeridum Theologicarum Lovaniensium 192, Leuven 2005, s. 217-223.

Kahle P., Die Lederrolle mit dem griechischen Text der Kleinen Propheten und das Problem der LXX, Theologische Literaturzeitung 79/1954, s. 81-94.

Kaminka A., Studien zur Septuaginta an der Hand der zwölf kleinen Prophetenbücher, Monatsschrift für Geschichte und Wissenschaft des Judentums 72, Breslau 1928.

Kellermann U., Israel und Edom. Studien zum Edomhass Israels in 6.-4. Jahrhundert v. Chr., Münster 1975.

Krause J.J., Tradition, history, and our story: some observations on Jacob and Esau in the books of Obadiah and Malachi, Journal for the Study of the Old Testament 32/2008, s. 475-486.

Księga Abdiasza, w: J.H. Walton, V.H. Matthews, M.W. Chavalas (red.), W. Chrostowski (red. nauk. wyd. pol.), Komentarz historyczno-kulturowy do Biblii Hebrajskiej, Prymasowska Seria Biblijna 24, Oficyna Wydawnicza „Vocatio”, Warszawa 2005, s. 890-892.

Lemaire A., La stèle de Mésha et l'histoire de l'ancien Israël, w: D. Garrone, F. Israel (red.), Storia e tradizioni di Israele, Paideia Editrice, Brescia 1991, s. 143-169.

Lemaire A., The Mesha Stele and the Omri Dynasty, w: L.L. Grabbe (red.), Ahab Agonistes, T \& T Clark, London 2007, s. 135-144. 
Lescow Th., Die Komposition des Buches Obadja, Zeitschrift für die alttestamentliche Wissenschaft 111/1999, s. 380-398.

Libro de los Doce Profetas, w: N. Fernàndez Marcos, M. Victoria Spottorno Díaz-Caro (kord.), La Biblia Griega. Septuaginta IV. Libros proféticos, Biblioteca de Estudios Bíblicos 128, Salamanca 2015 [Biblia Griega], s. 15-123; (Ksiegga Abdiasza, s. 69-72).

Lipiński E., Obadiah 20, Vetus Testamentum 23/1973, s. 368-370.

Luckensmeyer D., Intertextuality between Obadiah and First Thessalonians, w: C.A. Evans, H.D. Zacharias (red.), „What does the Scripture say?” Studies in the Function of Scripture in Early Judaism and Christianity, t. 2, T\& T Clark, London-New York 2012, s. 98-120.

Mallon E.D., Ksiegga Abdiasza, w: R.E. Brown, J.A. Fitzmyer, R.E. Murphy (red.), W. Chrostowski (red. wyd. pol.), Katolicki Komentarz Biblijny, Prymasowska Seria Biblijna 17, Oficyna Wydawnicza „Vocatio”, Warszawa 2001, s. 834-836.

Mason R., Micah, Nahum, Obadiah, OT Guides, JSOT Press, Sheffield 1991, s. 85-108.

McCarter P.K., Obadiah 7 and the Fall of Edom, Bulletin of the American Schools of Oriental Research 220-221(1975-1976)DEC-FEBR, s. 87-91.

Mouraoka T., In Defence of the Unity of the Septuagint Minor Prophets, Annual of the Japanese Biblical Institute 15/1989, s. 25-36.

Myers J.M., Edom and Judah in the Sixth-Fifth Centuries B.C., Near Eastern Studies (Fest. Albright), Baltimore 1971, s. 377-392.

Niccacci A., The Stele of Mesha and the Bible: Verbal System and Narrativity, Orientalia 63/1994, s. 226-248.

Nogalski J.D., Obadiah 7: Textual Corruption or Politically Charged Metaphor? Zeitschrift für die alttestamentliche Wissenschaft 110/1998, s. 67-71.

Nogalski J.D., Not Just Another Nation. Obadiah's Placement in the Book of the Twelve, w: R. Albertz, J.D. Nogalski, J. Wöhrle (red.), Perspectives on the Formation of the Book of the Twelve: Methodological Foundations Redactional Process - Historical Insights, De Gruyter, Berlin 2012, s. 89-107.

Offizielles Verzeichnis der Rahlfs-Sigeln. Herausgegeben vom Septuaginta-Unternehmen der Akademie der Wissenschaften zu Göttingen, Göttingen 2012.

Ogden G.S., Prophetic Oracles Against Foreign Nations and Psalms of Communal Lament: The Relationship of Psalm 137 to Jeremiah 49:7-22 and Obadiah, Journal for the Study of the Old Testament 24/1982, s. 89-97.

The Old Testament in Greek According to the Septuagint, t. III, red. H.B. Swete, The University Press, Cambridge $1922^{3}$. 
Renkema J., The Literary Structure of Obadiah, w: C.A.M. Korpel (red.), Delimitation Criticism, Royal Van Gorcum, Assen 2000, s. 230-276.

Renkema J., Data Relevant to the Dating of the Prophecy of Obadiah, w: H.F. Van Rooy (red.), Past, Present, Future: The Deuteronomistic History and the Prophets, Brill, Leiden 2000, s. 251-262.

Richelle M., La structure littéraire du livre d'Abdias, Biblische Notizen 169/2016, s. 27-45.

Rudolph W., Joel - Amos - Obadja - Jona, Kommentar zum Alten Testament XIII/2, Gere Mohn, Gütersloh 1971.

Salanga V., Księga Abdiasza, w: Międzynarodowy komentarz do Pisma Świętego. Komentarz katolicki i ekumeniczny na XXI wiek, red.nauk. W.R. Faarmer, współred. S. McEvenue, A.J. Levoratti, D.L. Dungan, red. nauk. wyd. polskiego W. Chrostowski, współred. T. Mieszkowski, P. Pachciarek, Verbinum - Wydawnictwo Księży Werbistów, Warszawa 2001, s. 1021-1024.

Sanders H.A., The Old Testament Manuscripts in the Freer Collection, 1917.

Schart A., Dodekapropheton. Das Zwölfprophetenbuch, w: M. Karrer, W. Kraus i in. (red.), Septuaginta Deutsch. Erläuterungen und Kommentare zum gieschischen Alten Testament, t. II: Psalme bis Daniel, Stuttgart 2009, s. 2275-2286.

Schmoll H., Utzschneider H., Abdiu. Obadja, w: M. Karrer, W. Kraus i in. (red.), Septuaginta Deutsch. Erläuterungen und Kommentare zum gieschischen Alten Testament, t. II: Psalmen bis Daniel, red. Stuttgart 2010, s. 2388-2393.

Septuaginta, czyli Biblia Starego Testamentu wraz z ksiegami deuterokanonicznymi i apokryfami, przekł., przypisy i wstępy R. Popowski, Prymasowska Seria Biblijna 37, Oficyna Wydawnicza „Vocatio”, Warszawa 2013 (Księga Abdiasza, s. 1329-1330).

Septuaginta Deutsch. Das griechische Alte Testament in deutcher Übersetzung, red. W. Kraus, M. Karrer i in., Stuttgart 2009 [SeptDeutsch]; (wprowadzenie do Dwunastu Proroków, s. 1165-1166 oraz s. 1195; przekład LXXAbd, s. 1195-1196).

Septuaginta. Id est Vetus Testamentum graece iuxta LXX interpretes, red. A. Rahlfs, R. Hanhart, Deutsche Bibelgessellschaft, Stuttgart 2006.

Septuaginta. Vetus Testamentum Graecum. Auctoritate Academiae Scientiarum Gottingensis editum, t. XV: Jeremias - Baruch-Threni-Epistula Jeremiae red. J. Ziegler, Vandenhoeck \& Ruprecht, Göttingen 1957.

Sgargi G., Gioele - Amos - Abdia: Versione ufficiale italiana confrontata con ebraico masoretico, greco dei Settanta, siriaco della Peshitta, latino della Vulgata, Biblia/Comunità di Monteveglio. AT 32-34, Edizioni Dehoniane Bologna, Bologna 1998. 
Sirikivuya Mumbere A., ,'Le règne à $Y H W H$ " : pour lire Abdias-Jonas et Michée, cas d'une cohérence polyphonique des XII dans le texte massorétique, w: H.-J. Fabry (red.), The Books of the Twelve Prophets: Minor Prophets - Major Theologies, Peeters, Leuven-Paris-Bristol 2018, s. 365-386.

Strzałkowska B., Księga Nahuma i Księga Jonasza: debata wewnatrz zbioru Dwunastu Proroków? Collectanea Theologica 81(2011)4, s. 29-46.

Strzałkowska B., Księga Aggeusza w Septuagincie, Collectanea Theologica 82(2012)4, s. 75-98.

Strzałkowska B., Ksiega Ozeasza w Septuagincie, Collectanea Theologica 86(2016)4, s. 77-102.

Sweeney M.A., The Twelve Prophets. Volume one: Hosea, Joel, Amos, Obadiah, Jonah, Berit Olam. Studies in Hebrew Narrative \& Poetry, The Liturgical Press, Collegville MI 2000.

Tov E., On Pseudo-Variants Reflected in the Septuagint, Journal of Semitic Studies 20/1975, s. 165-177.

Tov E., Approaches towards Scripture Embraced by the Ancient Greek Translators, w: U. Mittmann-Richert, F. Avemarie, G.S. Oegema (red.), Der Mensch vor Gott, Neukirchener, Neukirchen-Vluyn 2003, s. 213-228.

Treitel L., Wert und Bedeutung der Septuaginta zu den 12 kleinen Propheten, Monatsschrift für Geschichte und Wissenschaft des Judentums 73/1929, s.232-234.

The Twelve Minor Prophets = תרי עשר. Biblia Hebraica Quinta Editione cum Apparatu Critico Novis Curis Elaborato, t. 13, red. A. Gelston, Deustsche Bibelgesellschaft, Stuttgart 2010 [BHQ].

The Twelve Prophets = תרי עשר = Trei Asar: A New Translation with a Commentary Anthologized from Talmudic, Midrashic and Rabbinic Sources, t. 1-2, ArtScroll Tanach Series: A Traditional Commentary on the Books of the Bible, Mesorah Publications, New York 2009-2015.

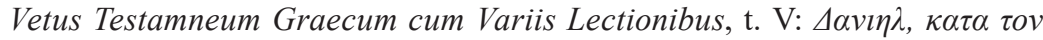

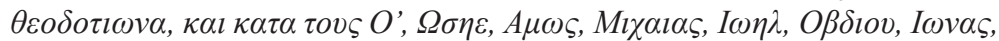

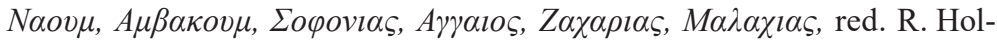
mes, J. Parsons, Oxonii E Typ., Clarendoniano, London-Oxford 1826 [Holmes-Parsons].

Weimar P., Obadja. Eine redaktionskritische Analyse, Biblische Notizen 27/1985, s. 35-99.

Weippert M., Edom. Studien zur Geschichte der Edomiter auf Grund schriftlicher un archäologischer Quellen, Tübingen 1971.

Weissert D., Obadiah 20: Septuagint and Vulgate, Textus: Studies of the Hebrew University Bible Project 24/2009, s. 85-106. 
Zenger E., Il libro dei Dodici profeti, w: tenże (red.), Introduzione all'Antico Testamento, Editrice Queriniana, Brescia 2013 (nowe wydanie włoskie), s. 848-948.

Ziegler J., Die Einheit der Septuaginta zum Zwölfprophetenbuch, Beilage zum Vorlegungsverzeichnis der Staatl. Akademie zu Braunsberg/Ostpr. 5/ 1934, s. 1-16.

Ziegler J., Studien zur Verwetung der Septuaginta im Zwölfprophetenbuch, Zeitschrift für die alttestamentliche Wissenschaft 60/1944, s. 107-131.

Ziegler J., Zur Dodekapropheton-LXX, Ephemerides Theologicae Lovanienses 38/1962, s. 904-906.

Strony internetowe:

Kodeks Watykański (Dwunastu Proroków od numeru karty 945; Księga Abdiasza to karty 972-973) na stronie internetowej ze zdigitalizowanymi rękopisami ze zbiorów Biblioteki Watykańskiej: http://digi.vatlib.it/view/MSS_Vat. gr.1209 [dostęp: 14 II 2020]. 